Trinity University

Digital Commons @ Trinity

$5-2013$

\title{
Understanding a Critical Basinal Link in Cretaceous Cordilleran \\ Paleogeography: Detailed Provenance of the Hornbrook Formation, Oregon and California
}

Kathleen D. Surpless

Trinity University, ksurples@trinity.edu

Emily J. Beverly

Trinity University

Follow this and additional works at: https://digitalcommons.trinity.edu/geo_faculty

Part of the Earth Sciences Commons

\section{Repository Citation}

Surpless, K. D., \& Beverly, E. J. (2013). Understanding a critical basinal link in Cretaceous Cordilleran paleogeography: Detailed provenance of the Hornbrook formation, Oregon and California. Geological Society of America Bulletin, 125(5-6), 709-727. doi: 10.1130/B30690.1

This Article is brought to you for free and open access by the Geosciences Department at Digital Commons @ Trinity. It has been accepted for inclusion in Geosciences Faculty Research by an authorized administrator of Digital Commons@ Trinity. For more information, please contact jcostanz@trinity.edu. 


\title{
Understanding a critical basinal link in Cretaceous Cordilleran paleogeography: Detailed provenance of the Hornbrook Formation, Oregon and California
}

\author{
Kathleen D. Surpless ${ }^{\dagger}$ and Emily J. Beverly ${ }^{\dagger, \S}$ \\ Department of Geosciences, Trinity University, One Trinity Place, San Antonio, Texas 78212, USA
}

\section{ABSTRACT}

The Hornbrook Formation is a Cretaceous overlap assemblage that rests unconformably on accreted terranes and plutons of the Klamath Mountains in southern Oregon and northern California. The combined results of sandstone petrography, detrital zircon $\mathrm{U}-\mathrm{Pb}$ age and Hf isotopic systematics, and wholerock Nd analysis document an abrupt change in sediment sources for the Hornbrook Formation during the Late Cretaceous. The lower members of the Hornbrook Formation record provenance in the Klamath Mountains and the Sierran Foothills belt that is characterized by detrital zircon age distributions with large Jurassic and Early Cretaceous peaks (170-130 Ma) and positive zircon Hf and whole-rock Nd values. In contrast, upper members of the Hornbrook Formation include abundant sediment derived from the Cretaceous Sierran Batholith that is characterized by large Cretaceous peaks (120$85 \mathrm{Ma})$ in detrital zircon age distributions and less positive zircon $\mathrm{Hf}$ and whole-rock $\mathrm{Nd}$ values. A similar Late Cretaceous provenance shift is present in the Great Valley Group of California, which likely formed the southern continuation of the Hornbrook basin during deposition of the upper Hornbrook members. These provenance results may reflect changing plate kinematics along the U.S. Cordilleran margin during the Late Cretaceous, including extension and subsidence in the Klamath Mountains and Blue Mountains regions followed by rapid uplift of the main Sierra Nevada Batholith. Thus, the detailed provenance signature for the Hornbrook

†E-mails: ksurpless@trinity.edu; Emily_Beverly@ baylor.edu.

${ }^{\S}$ Present address: Department of Geology, Baylor University, 101 Bagby Avenue, BSB D.409, Waco, Texas 76706, USA.
Formation presented here records regional tectonic events in the mid- to Late Cretaceous U.S. Cordillera, and suggests that the Hornbrook Formation and Great Valley Group shared similar sources but remained separate basins until mid- to Late Cretaceous time.

\section{INTRODUCTION}

The complex history of terrane accretion, translation, rotation, and magmatic events that characterizes the development of the North American Cordillera has been extensively studied and described (e.g., Burchfiel and Davis, 1972; Davis et al., 1978; Burchfiel et al., 1992; Cowan and Bruhn, 1992; Irving et al., 1996; Dickinson, 2004), but the Cretaceous paleogeography of many segments of the North American Cordillera remains unresolved (e.g., Cowan et al., 1997; Haggart et al., 2006). For example, restoring offset geologic features across Late Cretaceous to Cenozoic dextral strike-slip faults in the Cordillera limits total translation to tens to hundreds of kilometers (e.g., Gabrielse, 1985; Monger, 1991; Umhoefer and Schiarizza, 1996), but paleomagnetic data suggest as much as $3000 \mathrm{~km}$ of northward displacement for terranes now in British Columbia (Wynne et al., 1995; Irving et al., 1996).

Subduction spanned the west coast of North America during Cretaceous time, creating magmatic arcs and adjacent forearc basins that include the Methow basin in northern Washington, the Ochoco and Hornbrook basins in Oregon and northern California, and the Great Valley basin in California (Fig. 1; e.g., Burchfiel et al., 1992; Dickinson, 2004). During the Late Cretaceous, the Blue Mountains, Sierra Nevada Mountains, and Klamath Mountains may have been part of a single, relatively continuous magmatic arc, with the forearc basins associated with these mountain ranges forming one complex forearc basin along the west coast of North America (Nilsen, 1984; Miller et al., 1992). Wyld et al.'s (2006) 100 Ma reconstruction restores displacement on faults active since $100 \mathrm{Ma}$, as well as displacements within Late Cretaceous and Cenozoic contractional and extensional belts, bringing the Ochoco and Hornbrook basins together into one connected system, and suggesting that the Methow basin may represent the northern continuation of the combined Hornbrook-Ochoco basin.

These Cordilleran forearc basins may preserve a more complete record of Cretaceous magmatic and tectonic development than the modern, eroded remnants of the arc themselves. Therefore, characterizing the sedimentary provenance of these basins and assessing correlations between Cretaceous basins throughout the Cordillera may help determine the extent of post-Mesozoic terrane translation and test paleogeographic reconstructions. In this paper, we present detailed provenance analysis of the Hornbrook Formation, an Upper Cretaceous overlap assemblage that rests unconformably on Paleozoic, Triassic, and Jurassic rocks of the Klamath Mountains (Figs. 1 and 2; Nilsen, 1993). Dominantly north- and northeast-directed paleocurrent indicators, together with sandstone petrography, have been interpreted to indicate a Klamath Mountains source of sediment (Nilsen, 1984, 1993; Miller et al., 1992). We present the results of sandstone petrography, detrital zircon U-Pb age and $\mathrm{Hf}$ isotopic systematics, and whole-rock Nd analysis throughout the Hornbrook Formation to provide a more detailed and complete provenance signature that records changing sediment sources through time.

Our results suggest that the Klamath Mountains may have provided a significant sediment source only for the lower members of the Hornbrook Formation. The upper Hornbrook Formation provenance records an abrupt shift in sediment sources during the Late Cretaceous, requiring significant sediment input from the main Cretaceous batholith of the Sierra Nevada, located southeast of the basin (Fig. 1). We

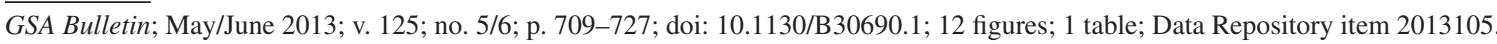




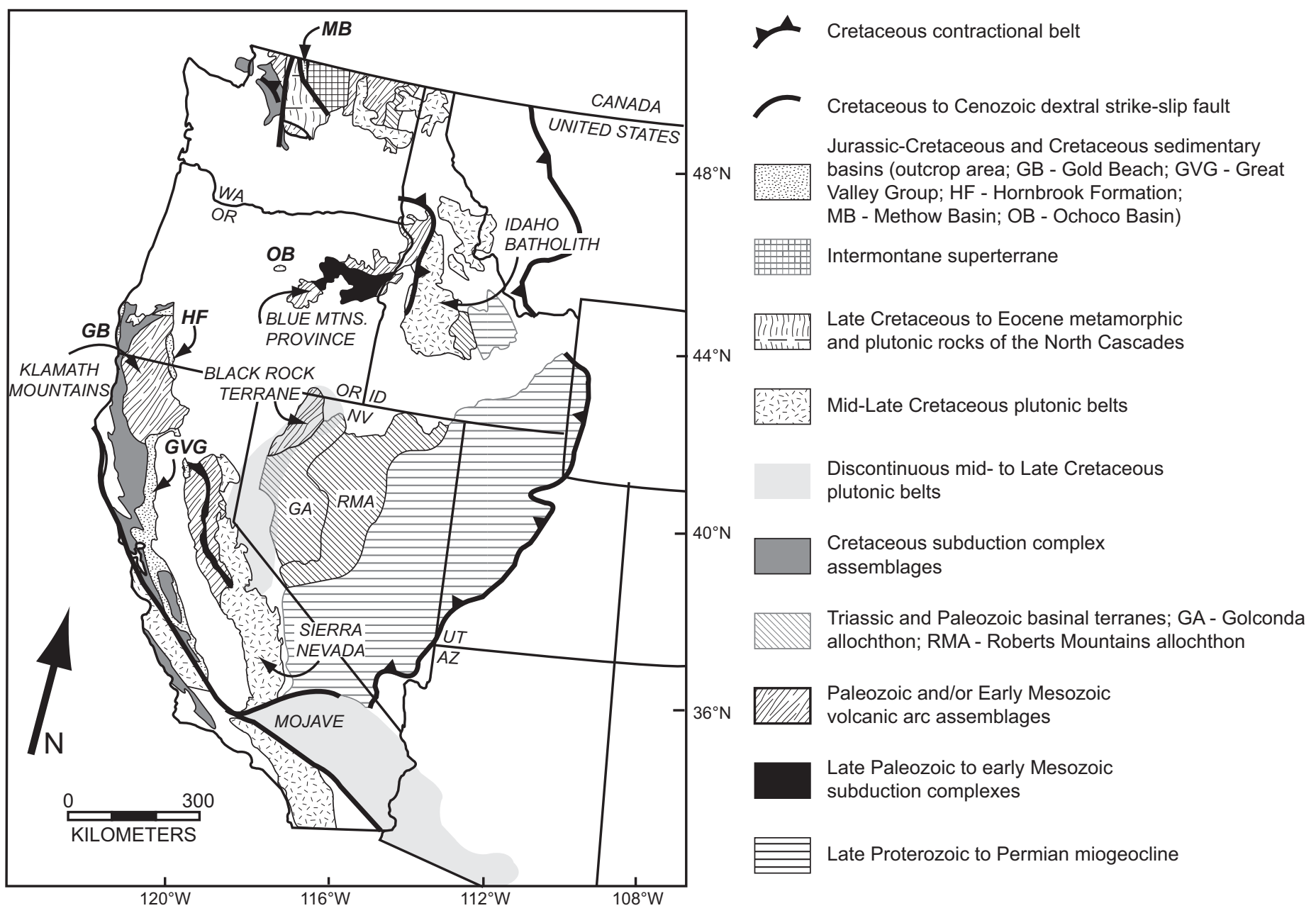

Figure 1. Generalized map of the U.S. Cordillera (modified from Wyld et al., 2006). GB—Gold Beach; GVG-Great Valley Group; HFHornbrook Formation; OB-Ochoco Basin; MB-Methow Basin.

suggest that this provenance change occurred as magmatism and deformation shifted to the east with shallowing of Farallon plate subduction (Dickinson, 2004; Liu et al., 2008), and as the Kula plate separated from the Farallon plate and began moving north through oblique subduction (Woods and Davies, 1982; Engebretson et al., 1985). Similar provenance and provenance changes in the Late Cretaceous Great Valley Group suggest that the sedimentary strata of both basins record regional tectonic events of the Late Cretaceous Cordillera, and that these basins formed one, single depositional system during the Late Cretaceous, from Santonian through Maastrichtian time.

\section{GEOLOGY OF THE HORNBROOK FORMATION}

The Hornbrook Formation rests unconformably on Paleozoic and Mesozoic accreted terranes and plutons of the Klamath Mountains
(Irwin, 1981; Nilsen, 1984) and is unconformably overlain by Paleogene sedimentary and volcanic rocks of the Cascade Range (McKnight, 1971). The Hornbrook Formation is exposed in a northwest-trending belt on the eastern flank of the Klamath Mountains and is offset by numerous northeast-trending faults (Figs. 1 and 2). Nilsen (1984) subdivided the Hornbrook Formation into five members, building on the mapping and stratigraphy of previous workers (Fig. 3; Peck et al., 1956; Jones, 1959; McKnight, 1971; Elliott, 1971). The strata of the Hornbrook Formation record marine transgression in a subsiding basin with deposits grading from fluvial/alluvial to slope and deep basin plain, followed by minor relative sea-level regressions evident in the upper Hornbrook Formation that shift depositional environments to the outer shelf (Fig. 3).

The Hornbrook Formation is generally timetransgressive, with deposition occurring as early as late Albian (ca. $102 \mathrm{Ma}$; time scale of Walker and Geissman, 2009) in the north and continuing into Maastrichtian time (70.6-65.5 Ma; time scale of Walker and Geissman, 2009) in the south (Nilsen, 1993). Rare marine acritarchs and abundant pollen from the southern Klamath River Conglomerate member yield a middle Cenomanian age (ca. 95 Ma; Jameosannaie and Lindsley-Griffin, 1993), but no other fossil data have been reported from the basal Hornbrook Formation. Several workers have described an unconformity within the Hornbrook Formation that spans as much as Coniacian and early Campanian time (89.3-78 Ma; Peck et al., 1956; Elliott, 1971), but Nilsen (1993) reported megaand microfossil ages that indicate the proposed unconformity may be a local erosional feature that is not basinwide.

Sandstone petrography throughout the Hornbrook Formation is relatively uniform (Fig. 4; Table 1), with samples from all five members plotting together in transitional continental, basement uplift, and recycled orogen provenance 


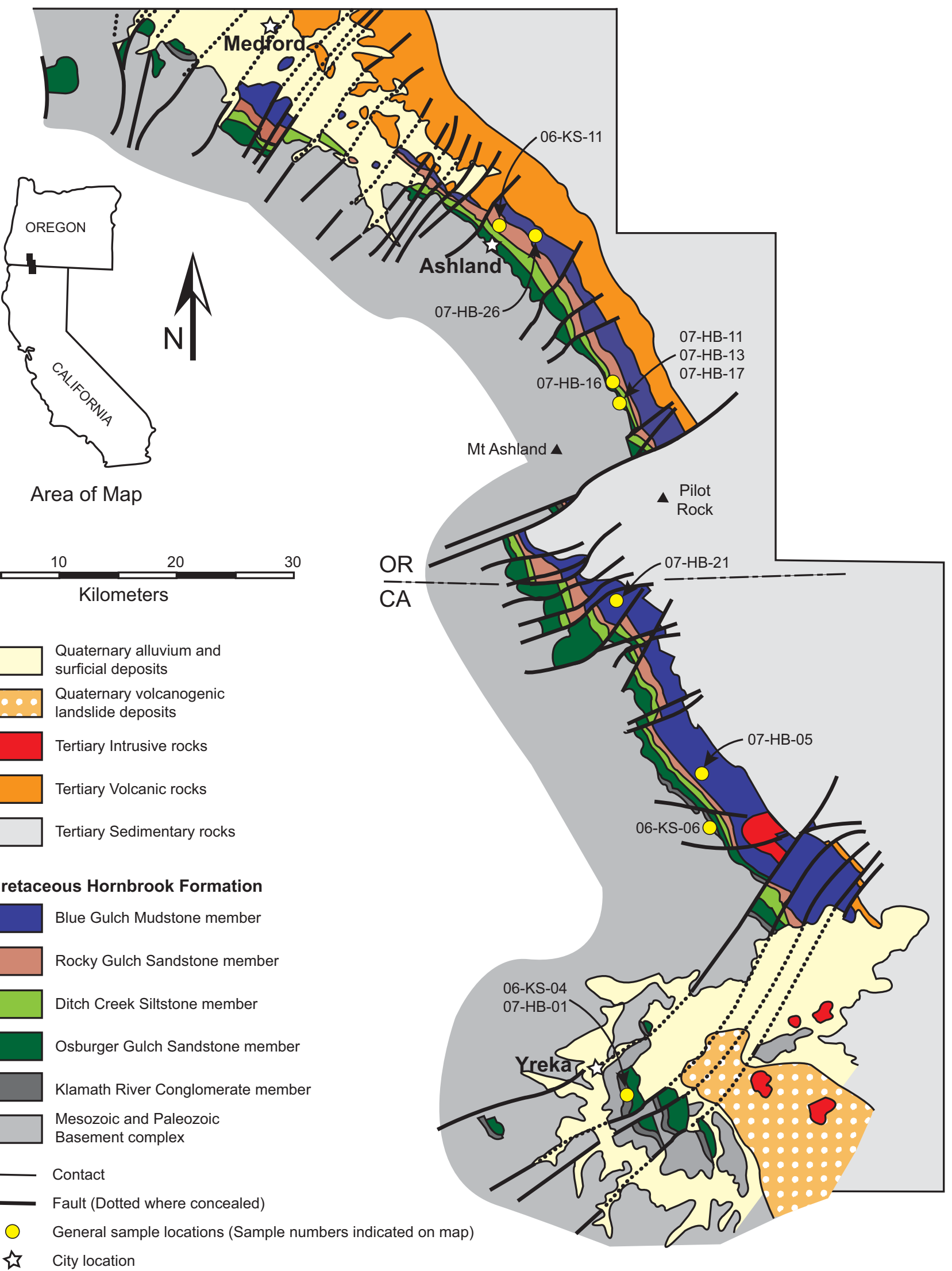

Figure 2. Simplified geologic map of the Hornbrook Formation (from Nilsen, 1993). General sample localities are indicated by yellow circles with sample numbers. 


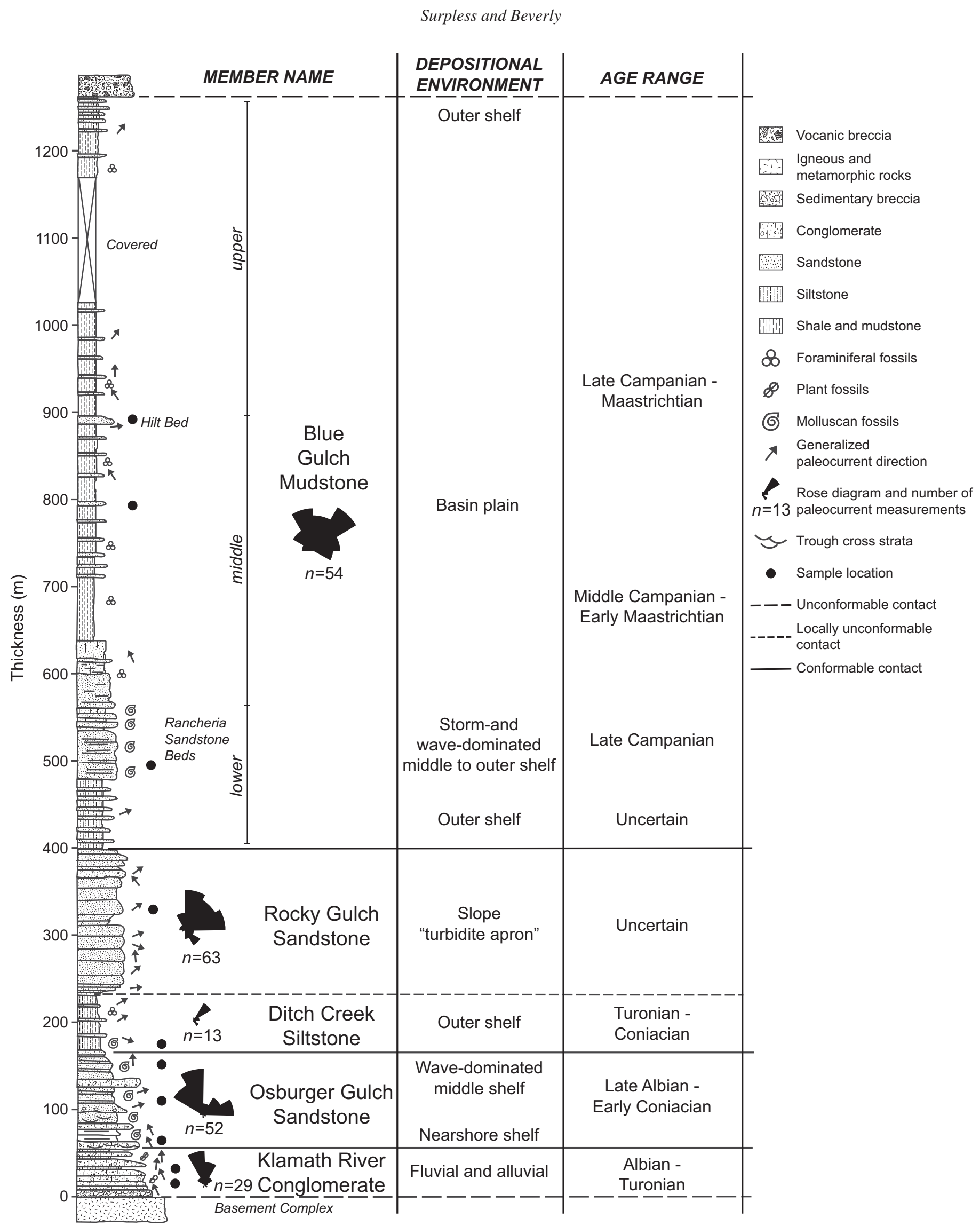

Figure 3. Composite measured section of the Hornbrook Formation (modified from Nilsen, 1993). Paleocurrent rose diagrams are from Nilsen (1984); depositional environments and age ranges are from Nilsen (1984, 1993). Approximate sample locations are indicated by black circles. 


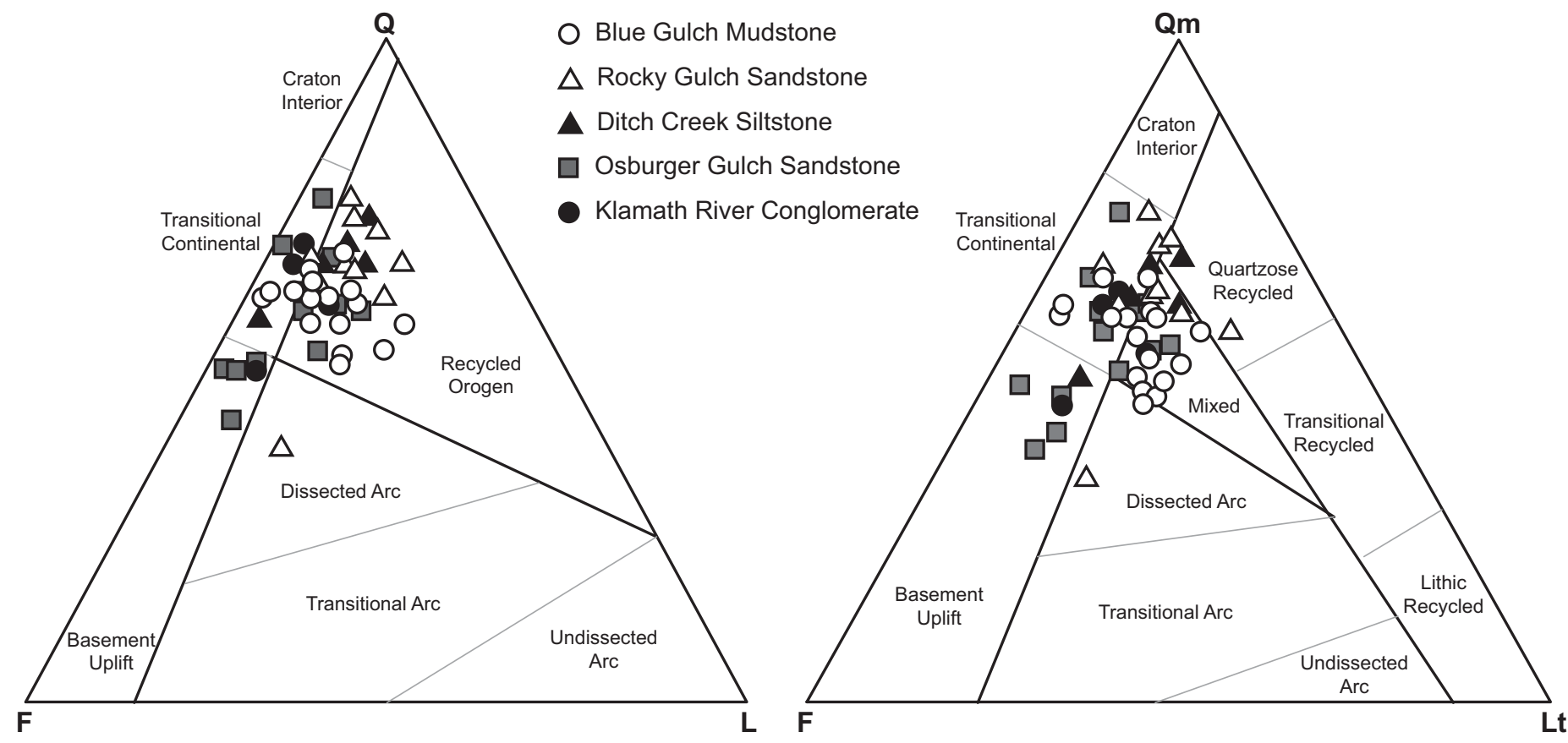

Figure 4. Ternary diagrams illustrating sandstone detrital modes. Tectonic provenance fields are from Dickinson et al. (1983); Q-total quartz, Qm-monocrystalline quartz, F-total feldspar, L-lithic grains, excluding polycrystalline quartz, and Lt—-total lithic grains. Data are from Golia and Nilsen (1984) and this study.

fields of Dickinson et al. (1983; data from this study; Golia and Nilsen, 1984). Sandstone petrography reveals a lack of volcanic lithic grains, although the presence of chloritized matrix and calcitization of framework grains suggest that early diagenesis may have altered original unstable volcanic lithic grains (Bywater and Elliott, 2007). Paleocurrent directions are generally to the north and northeast, with considerable scatter to the northwest (Fig. 3; Nilsen, 1984).

\section{DETRITAL ZIRCON AGE DISTRIBUTIONS AND HAFNIUM ISOTOPIC SIGNATURES}

Nine sandstone samples and one sample of quartzite cobbles were collected from four members of the Hornbrook Formation. Zircons were isolated using standard separation techniques (e.g., Gehrels et al., 2006). A random subset of zircon grains from each sample was mounted in epoxy and polished to approximately half thickness to expose zircon centers. $\mathrm{U}-\mathrm{Pb}$ age dating and $\mathrm{Lu}-\mathrm{Hf}$ isotopic analysis were completed at the LaserChron Center at the University of Arizona, following the methods described in Gehrels et al. (2006) and Cecil et al. (2011). Discordance is difficult to measure in grains younger than $600 \mathrm{Ma}$ due to the small amount of radiogenic $\mathrm{Pb}$ in younger zir- con. Following DeGraaff-Surpless et al. (2003), we included grains younger than $600 \mathrm{Ma}$ that plot within $10 \%$ of Tera-Wasserburg concordia along a mixing line from the common $\mathrm{Pb}$ value $\left({ }^{207} \mathrm{~Pb} /{ }^{206} \mathrm{~Pb}\right.$ ratio of 0.86 ; Cumming and Richards, 1975) through the data to concordia. For grains older than $600 \mathrm{Ma}$, only grains with less than $10 \%$ discordance were included in the probability density plots shown in Figure 5. Ages reported are ${ }^{206} \mathrm{~Pb} /{ }^{238} \mathrm{U}$ ages for grains younger than $900 \mathrm{Ma}$ and ${ }^{207} \mathrm{~Pb} /{ }^{206} \mathrm{~Pb}$ ages for grains $900 \mathrm{Ma}$ and older (all $\mathrm{U}-\mathrm{Pb}$ data are given in Table DR $1^{1}$ ). Initial $\mathrm{Hf}$ data were collected from selected 130-150 Ma and 85-100 Ma grains in four samples, using laser ablation of the same spot created during U-Pb analysis (all Hf data are given in Table DR2 [see footnote 1]).

The nine sandstone samples are characterized by Mesozoic ages (91\%; 679 grains; Fig. 5), with Precambrian grains accounting for $7 \%$ (51 grains; Fig. 6) of the 747 concordant to slightly discordant grains, and Paleozoic grains totaling only $2 \%$ (17 grains). Paleozoic grains are present in four of the nine sandstone samples but do not form any meaningful age peaks (including

'GSA Data Repository item 2013105, detrital zircon U-Pb and $\mathrm{Hf}$ data, is available at http://www .geosociety.org/pubs/ft2013.htm or by request to editing@geosociety.org. three or more grains; Dickinson and Gehrels, 2009a) and therefore are not discussed further.

The two Klamath River Conglomerate sandstone samples contain different proportions of Middle Jurassic and Early Cretaceous ages. The youngest robust age peaks are $141 \mathrm{Ma}$ in 06-KS-04 and $137 \mathrm{Ma}$ in 06-KS-06, and the youngest single grains are $134 \pm 8 \mathrm{Ma}$ in 06-KS-04 and $133 \pm 2$ Ma in 06-KS-06. Several small $(<4 \mathrm{~cm})$ quartzite cobbles collected from the southern outcrop of the Klamath River Conglomerate yielded only Precambrian ages, with 72 grains spanning 1111-3259 Ma; these grains form a broad 1800-2000 Ma peak, and smaller peaks at $1150,1325,2150,2300$, and $2600 \mathrm{Ma}$ (07-HB-01; Fig. 6). The ages of 10 Precambrian detrital zircon grains in the southern Klamath River Conglomerate sandstone sample (06-KS-04; Fig. 1) overlap with ages found in these quartzite cobbles, with peaks at 1800-1900, 2000, and $2200 \mathrm{Ma}$ (Fig. 6).

All three Osburger Gulch Sandstone samples contain abundant Early Cretaceous and Late Jurassic grains, with fewer Middle and Early Jurassic grains (Fig. 5). Four Precambrian grains comprise less than $2 \%$ of the total Osburger Gulch Sandstone grains analyzed (4 out of 239) and do not overlap within two sigma uncertainty. Youngest ages of three or more overlapping grains in the Osburger Gulch Sandstone samples are $128 \mathrm{Ma}$ (three grains; 
TABLE 1. RECALCULATED MODAL POINT-COUNT DATA FOR SANDSTONE SAMPLES FROM THE HORNBROOK FORMATION

\begin{tabular}{|c|c|c|c|c|c|c|c|c|}
\hline \multirow[b]{2}{*}{ Member } & \multirow[b]{2}{*}{ Sample no. } & \multirow[b]{2}{*}{ Total } & \multicolumn{3}{|c|}{ Q-F-L (\%) } & \multicolumn{3}{|c|}{ Qm-F-Lt (\%) } \\
\hline & & & $Q$ & $\mathrm{~F}$ & $\mathrm{~L}$ & $\mathrm{Qm}$ & $\mathrm{F}$ & $\mathrm{Lt}$ \\
\hline \multirow[t]{15}{*}{ Blue Gulch Mudstone } & 82TN 31C & 100 & 65 & 28 & 7 & 63 & 29 & 8 \\
\hline & $82 \mathrm{TN} 38 \mathrm{~L}$ & 100 & 62 & 24 & 14 & 59 & 24 & 17 \\
\hline & $82 T N 41$ & 100 & 53 & 24 & 23 & 51 & 24 & 25 \\
\hline & 82TN 47C & 100 & 60 & 28 & 12 & 58 & 28 & 14 \\
\hline & 82TN 82B & 100 & 51 & 31 & 18 & 49 & 31 & 20 \\
\hline & 82TN 83B & 100 & 60 & 24 & 16 & 58 & 24 & 18 \\
\hline & 82TN 86B & 100 & 68 & 22 & 10 & 64 & 22 & 14 \\
\hline & 82TN 86D & 100 & 57 & 28 & 15 & 55 & 28 & 17 \\
\hline & 82TN 88 & 100 & 57 & 19 & 24 & 56 & 19 & 25 \\
\hline & $82 \mathrm{TN} 178 \mathrm{~B}$ & 100 & 61 & 30 & 9 & 58 & 30 & 12 \\
\hline & 07-HB-04 & 400 & 62 & 35 & 3 & 60 & 35 & 5 \\
\hline & 07-HB-05 & 400 & 61 & 37 & 2 & 58 & 37 & 5 \\
\hline & $07-\mathrm{HB}-21^{*}$ & 400 & 57 & 32 & 11 & 45 & 32 & 23 \\
\hline & $07-H B-26^{*}$ & 400 & 64 & 28 & 8 & 52 & 28 & 20 \\
\hline & 07-HB-28 & 400 & 62 & 31 & 7 & 47 & 31 & 22 \\
\hline \multirow[t]{10}{*}{ Rocky Gulch Sandstone } & 81TN 39 & 100 & 66 & 15 & 19 & 56 & 15 & 29 \\
\hline & 82TN 08A & 100 & 63 & 28 & 9 & 60 & 28 & 12 \\
\hline & $82 T N 08 C$ & 100 & 66 & 23 & 11 & 61 & 23 & 16 \\
\hline & $82 \mathrm{TN} 08 \mathrm{H}$ & 100 & 67 & 27 & 6 & 66 & 27 & 7 \\
\hline & 82TN 48A & 100 & 71 & 16 & 13 & 70 & 16 & 14 \\
\hline & 82TN 99 & 100 & 76 & 17 & 7 & 74 & 17 & 9 \\
\hline & $82 \mathrm{TN} 110$ & 100 & 65 & 22 & 13 & 62 & 22 & 16 \\
\hline & 82TN 135 & 100 & 73 & 18 & 9 & 69 & 18 & 13 \\
\hline & 83TN 25 & 100 & 61 & 20 & 19 & 59 & 20 & 21 \\
\hline & 08-HB-30 & 400 & 38 & 46 & 16 & 34 & 46 & 20 \\
\hline \multirow[t]{5}{*}{ Ditch Creek Siltstone } & 82TN 05A & 100 & 69 & 21 & 10 & 66 & 21 & 13 \\
\hline & 82TN 05G & 100 & 66 & 20 & 14 & 60 & 20 & 20 \\
\hline & 82TN 05I & 100 & 66 & 26 & 8 & 61 & 26 & 13 \\
\hline & 82TN 165 & 100 & 73 & 16 & 11 & 67 & 16 & 17 \\
\hline & $07-\mathrm{HB}-16$ & 400 & 58 & 39 & 3 & 49 & 39 & 12 \\
\hline \multirow[t]{14}{*}{ Osburger Gulch Sandstone } & 82TN 02A & 100 & 69 & 30 & 1 & 64 & 30 & 6 \\
\hline & 82TN 02C & 100 & 59 & 32 & 9 & 56 & 32 & 12 \\
\hline & 82TN 02E & 100 & 62 & 31 & 7 & 59 & 31 & 10 \\
\hline & 82 TN 20 & 100 & 60 & 27 & 13 & 53 & 27 & 20 \\
\hline & 82TN 21 & 100 & 59 & 24 & 17 & 54 & 24 & 22 \\
\hline & 82TN 26 & 100 & 67 & 24 & 9 & 60 & 24 & 16 \\
\hline & 82TN 35B & 100 & 66 & 26 & 8 & 59 & 26 & 15 \\
\hline & 82TN 56 & 100 & 53 & 33 & 14 & 50 & 33 & 17 \\
\hline & 82TN 141 & 100 & 76 & 21 & 3 & 74 & 21 & 5 \\
\hline & 83TN 88A & 100 & 59 & 32 & 9 & 56 & 32 & 12 \\
\hline & $07-\mathrm{HB}-11^{*}$ & 400 & 50 & 47 & 3 & 48 & 47 & 5 \\
\hline & $07-\mathrm{HB}-13^{*}$ & 400 & 51 & 43 & 6 & 46 & 43 & 11 \\
\hline & 07-HB-14 & 400 & 43 & 50 & 7 & 38 & 50 & 12 \\
\hline & $07-\mathrm{HB}-17^{*}$ & 400 & 50 & 46 & 4 & 41 & 46 & 13 \\
\hline \multirow[t]{4}{*}{ Klamath River Conglomerate } & 82TN 17A & 100 & 69 & 27 & 4 & 62 & 27 & 11 \\
\hline & 82TN 17B & 100 & 66 & 30 & 4 & 60 & 30 & 10 \\
\hline & 07-HB-02 & 400 & 60 & 28 & 12 & 53 & 28 & 19 \\
\hline & 07-HB-09 & 400 & 50 & 43 & 7 & 45 & 43 & 12 \\
\hline
\end{tabular}

*Detrital zircon sample.

Abbreviations: Q-total quartzose grains, including chert and polycrystalline quartz; F-all monocrystalline feldspar grains; L_all nonquartzose polycyrstalline lithic fragments; Qm—monocrystalline quartz grains; Lt—all polycrystalline lithic grains, including polycrystalline quartz.

lower sample, 07-HB-11), $133 \mathrm{Ma}$ (nine grains, middle sample, 07-HB-13), and $134 \mathrm{Ma}$ (four grains, upper sample, 07-HB-17). The middle Osburger Gulch Sandstone sample (07-HB-13) contains two Late Cretaceous grains $(87 \pm 1$ and $89 \pm 1 \mathrm{Ma}$ ), whereas the youngest single grains in the other two samples are $127 \pm 2 \mathrm{Ma}$ in the lower sample (07-HB-11) and $133 \pm 1 \mathrm{Ma}$ in the upper sample (07-HB-17).

Lu-Hf isotopic analyses of 130-150 Ma grains in the southern Klamath River Conglomerate sample (06-KS-04) and the middle and upper Osburger Gulch Sandstone samples is $87 \mathrm{Ma}$ (six grains), and the youngest single grain is $83 \pm 5 \mathrm{Ma}$. The youngest age of three or more overlapping grains in the Rancheria Gulch Sandstone Beds is $87 \mathrm{Ma}$ (three grains), and the youngest single grain is $85 \pm 1 \mathrm{Ma}$. Precambrian grains in the Rancheria Sandstone Beds form two broad age peaks at 1300-1500 Ma and 1600-1800 Ma; the two Precambrian grains in the Rocky Gulch Sandstone fall within the 1300-1500 Ma peak. Lu-Hf isotopic analysis of the 85-100 Ma grains in the Rocky Gulch Sandstone sample yields a wide range in $\varepsilon_{\mathrm{Hf}}$ values, from +13.1 to -9.6 (Fig. 7).

The Blue Gulch Mudstone sample (07-HB-26) and the Hilt Bed sample of the Blue Gulch Mudstone member (07-HB-21) each contain Early Cretaceous and Middle and Early Jurassic grains, with few or no Late Cretaceous grains, and six Precambrian grains (Figs. 5 and 6). The youngest robust peak in the Blue Gulch Mudstone is $91 \mathrm{Ma}$ (six grains), and the youngest single grain is $90 \pm 1 \mathrm{Ma}$. The youngest robust peak in the Hilt Bed is $106 \mathrm{Ma}$ (seven grains), and the youngest single grain is $104 \pm 1 \mathrm{Ma}$.

\section{WHOLE-ROCK NEODYMIUM ISOTOPIC SIGNATURES}

The whole-rock Nd isotopic composition of sedimentary rocks is generally considered to be independent of grain size because $\mathrm{Sm} / \mathrm{Nd}$ is not significantly disturbed by weathering processes and is similar in most minerals (Goldstein et al., 1984; Linn et al., 1992). DePaolo and Wasserburg (1976) developed $\varepsilon_{\mathrm{Nd}}$ notation to address the limited relative fractionation between $\mathrm{Sm}$ and Nd during crystal-liquid properties, representing deviations from the chondritic uniform reservoir (CHUR) evolution line in parts per 10,000 and effectively normalizing all $\mathrm{Nd}$ data to CHUR. As with $\varepsilon_{\mathrm{Hf}}$, negative $\varepsilon_{\mathrm{Nd}}$ values indicate involvement of evolved, crustal rocks, while positive values indicate more juvenile mantle sources. DePaolo (1981) demonstrated that $\varepsilon_{\mathrm{Nd}}$ values closely correlate with initial ${ }^{87} \mathrm{Sr} /{ }^{86} \mathrm{Sr}$ values in the Sierra Nevada Batholith, and $\varepsilon_{\mathrm{Nd}}$ values in the Sierra Nevada Mountains range from -16 in Precambrian metasedimentary country rocks to +8 in primitive oceanicisland arc rocks; plutonic rocks in the Sierra Nevada Batholith range from -7.6 to +6.5 , with the most positive values in the western and northern parts of the batholith.

$\mathrm{Nd}$ isotopic analysis on eight Hornbrook sandstone samples revealed that older strata have more juvenile (positive $\varepsilon_{\mathrm{Nd}}$ ) sources, and younger strata have more evolved (negative $\varepsilon_{\mathrm{Nd}}$ ) sources (Fig. 8). The three Osburger Gulch Sandstone samples are very similar, with $\varepsilon_{\mathrm{Nd}}$ values of +4.1 to +4.3. The Ditch Creek Siltstone sample is also 


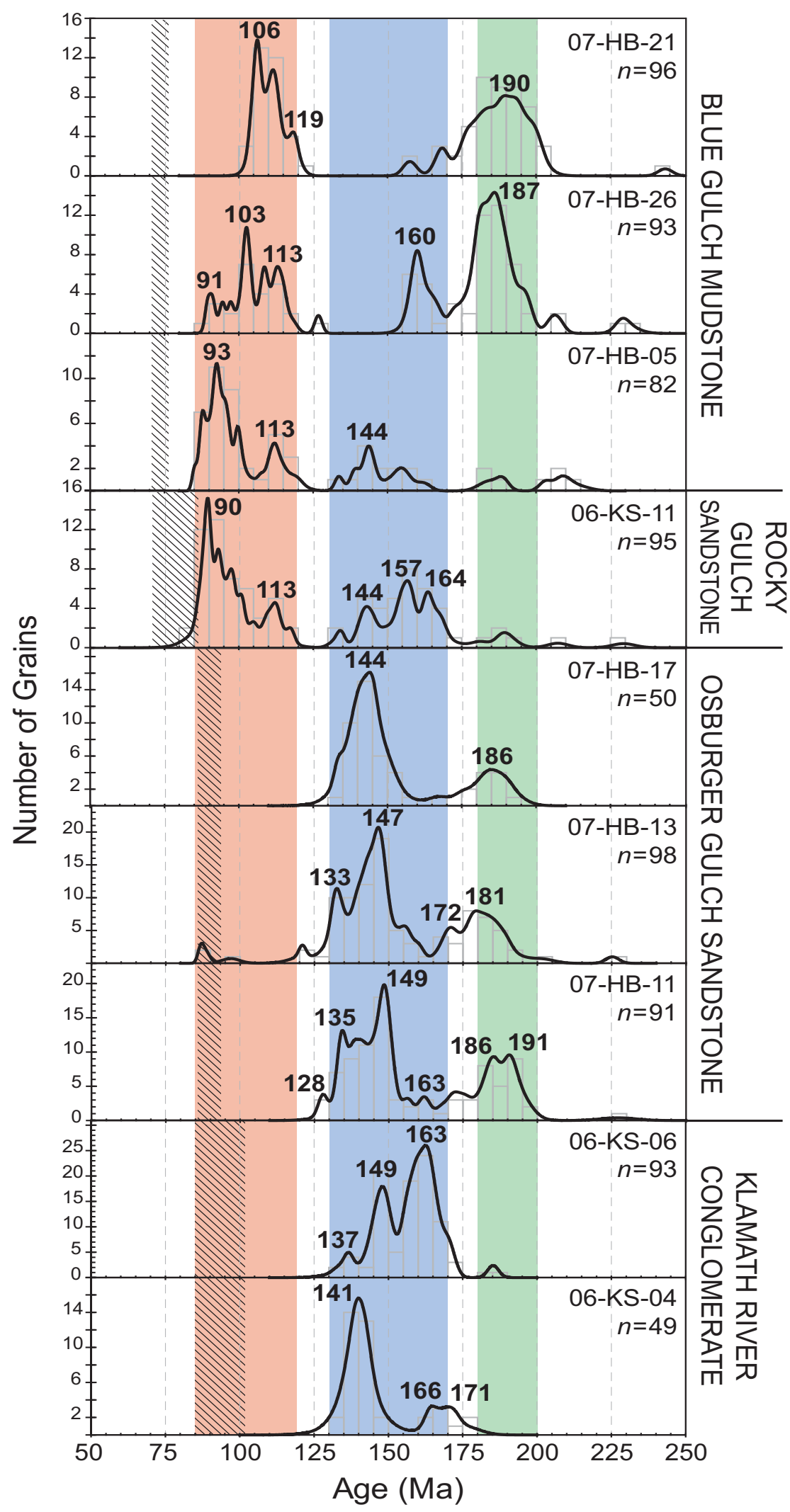

Figure 5. Histograms and superimposed probability density plots of detrital zircon age data for Mesozoic grains in the Hornbrook Formation. Curves are arranged in stratigraphic order, with the Klamath River Conglomerate at the bottom. Depositional age range is indicated by diagonal stripe pattern; colored vertical bars highlight key age ranges discussed in the text. positive, with $\varepsilon_{\mathrm{Nd}}$ of +2.7 . The $\varepsilon_{\mathrm{Nd}}$ signatures shift to more negative values in the Rocky Gulch Sandstone and Blue Gulch Mudstone members, ranging from -1.68 to -6.9 . The very negative Rancheria Gulch Sandstone beds value $(-6.9)$ is likely influenced by significant Precambrian source material, as indicated by the abundant Precambrian detrital zircon in this sample (Fig. 6).

\section{DISCUSSION}

\section{Hornbrook Formation Depositional Age Constraints}

In all Hornbrook Formation samples, the youngest detrital zircon ages provide maximum depositional ages that do not conflict with biostratigraphy. In the lower two members of the Hornbrook Formation, the youngest robust detrital zircon age is significantly older than available biostratigraphic ages, providing no improvement in depositional age control and permitting significant time for exhumation and erosion of source material before deposition in the Hornbrook basin. The likely Albian to Turonian depositional age of the Klamath River Conglomerate is based on biostratigraphy of the conformably overlying Osburger Gulch Formation, and requires at least an $\sim 30$ m.y. lag time between zircon crystallization and deposition in the basin. The 87 and 89 Ma grains in the middle Osburger Gulch Sandstone sample fall within the Turonian to Coniacian (93.5-85.8 Ma; time scale of Walker and Geissman, 2009) depositional age range, and would require Coniacian or later deposition if they represent the true maximum depositional age; however, they could also result from unrecognized $\mathrm{Pb}$ loss and therefore do not constitute a robust age peak.

In the upper two members of the Hornbrook Formation, the youngest detrital zircon ages are closer to depositional ages. The youngest robust detrital zircon age in the Rocky Gulch Sandstone member is $86 \mathrm{Ma}$, limiting deposition to Santonian to late Campanian time (85.8-70.5 Ma). The youngest robust age peak in the Rancheria Gulch Sandstone Beds is $88 \mathrm{Ma}$, at least $12 \mathrm{~m} . \mathrm{y}$. older than the well-constrained late Campanian (76-70.5 Ma) biostratigraphic age. The youngest robust peaks in the Blue Gulch Mudstone member and the Hilt Bed of the Blue Gulch Mudstone member are consistent with late Turonian to Maastrichtian (90.5-65.5 Ma) deposition.

Because of the time-transgressive nature of Hornbrook deposition, these maximum depositional ages do not permit improved basinwide constraints on the extent and duration of a possible disconformity between the Ditch Creek Siltstone and Rocky Gulch Sandstone members of the Hornbrook Formation. 


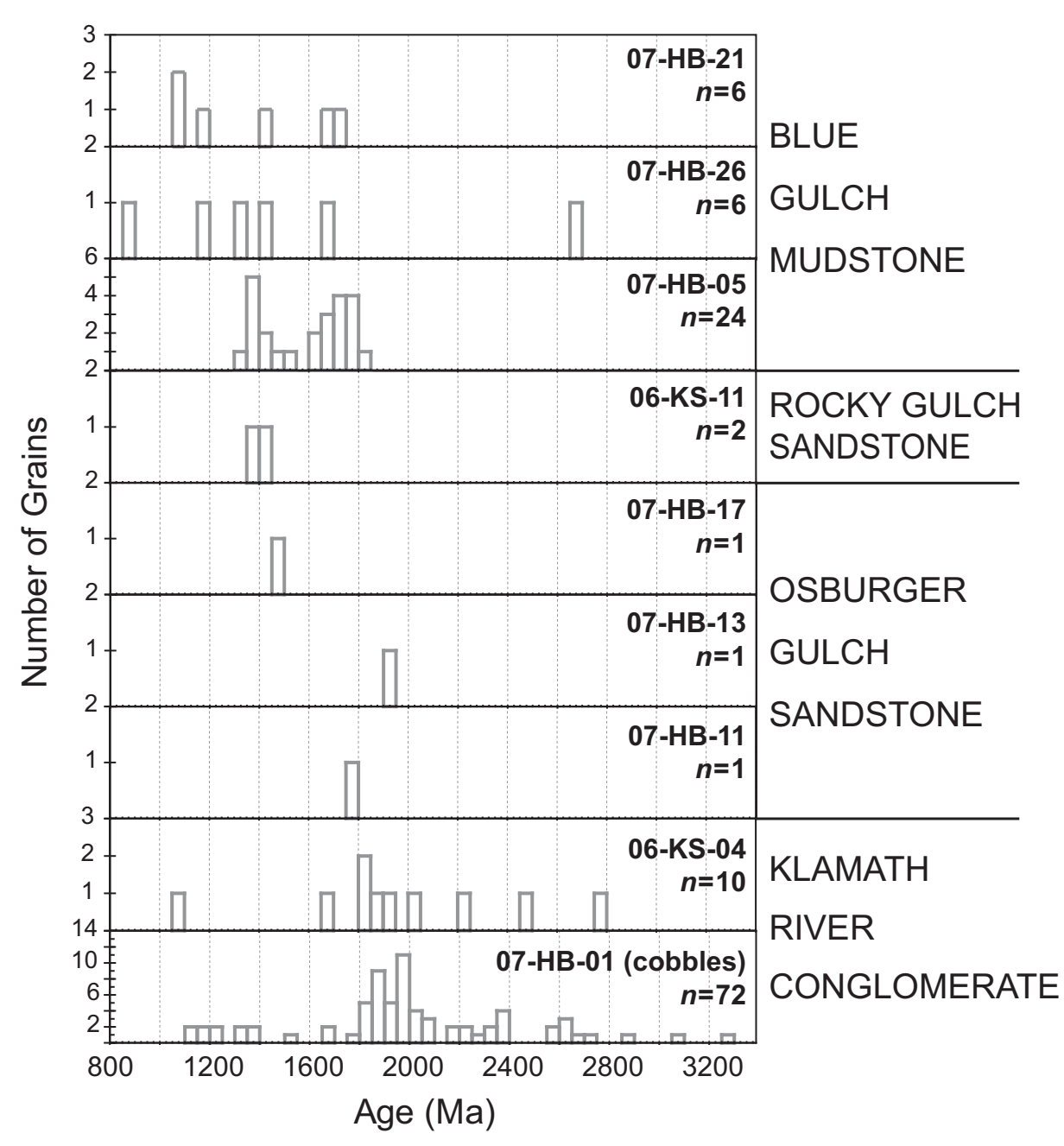

Figure 6. Histograms of detrital zircon age data for Precambrian grains from the Hornbrook Formation.

\section{Interpreting Hornbrook Formation Provenance}

Variability in provenance signatures depends, in part, on the catchment size of drainage systems that delivered sediment to a basin. First-order drainages include small alluvial and fluvial systems, second-order fluvial systems drain mountain ranges, and third-order fluvial and marine systems drain multiple mountain ranges (Ingersoll et al., 1993; Critelli et al., 1997). Although active magmatic arcs tend to yield uniform sandstone petrography results at any sampling scale due to the similarity of source rocks in these tectonic settings (Ingersoll et al., 1993), the ages of source rocks may retain more hetereogeneity. First- and even secondorder sandstone may have greater heterogeneity in detrital zircon age spectra, reflecting diversity in source rock ages and input from small tributaries; third-order sandstone has the potential to include the full range of source rock ages present in the source area for the basin (DeGraaffSurpless et al., 2003).

Statistical analysis suggests that 117 zircon grains from each sandstone sample must be dated to be $95 \%$ certain to detect all ages that represent at least $5 \%$ of the source area (Vermeesch, 2004); many detrital zircon studies attempt to analyze 100 grains per sample in an effort to identify all major age populations and their relative proportions in a source region (e.g., Gehrels et al., 2006). However, even if many more than 100 grains are analyzed, the resulting age spectra may miss source rocks, given that not all rocks yield significant detrital zircon. Zircon solubility in igneous source rocks depends on $\mathrm{H}_{2} \mathrm{O}$ content, melt temperature, and silica saturation (e.g., Watson and Harrison, 1983), such that zircon generally does not become abundant unless a melt is intermediate to felsic in composition (Poldervaart, 1956).
Detrital zircon rarely occurs in samples lacking detrital quartz (Gehrels et al., 2006), and most detrital zircon is derived from felsic to intermediate igneous rocks and recycled clastic sedimentary or metasedimentary successions (Gehrels, 2000; Dickinson and Gehrels, 2009b; LaMaskin et al., 2011).

Detrital zircon grains in the Hornbrook Formation are euhedral to subhedral, often display oscillatory zoning characteristic of magmatic growth (Hanchar and Miller, 1993), are typically larger than $100 \mu \mathrm{m}$, and lack visual evidence of inherited cores under cathodoluminescence. Given the large, equant character of Hornbrook Formation detrital zircons, the abundance of Mesozoic detrital zircon grains $(91 \%)$, and the very limited presence of Paleozoic (2\%) and Precambrian $(7 \%)$ detrital zircons, Hornbrook detrital zircon ages are likely biased toward igneous source rocks, suggesting that relatively few detrital zircons were recycled from older sedimentary and metasedimentary sources. In addition, the lack of volcanic lithic fragments in the Hornbrook Formation (Fig. 4) suggests that volcanic igneous rocks are not well represented in detrital zircon age distributions. Therefore, detrital zircon provenance interpretations presented here are based on correlating ages present in the Hornbrook Formation with plutonic ages in potential source regions, recognizing that detrital zircon may also be derived from coeval volcanic and hypabyssal igneous rocks as well as recycled sedimentary rocks. Our interpretations do not hinge on the absence of grains of a particular age in a detrital zircon age distribution because that absence may be due to catchment size (e.g., Ingersoll et al., 1993), drainage systems (e.g., DeGraaff-Surpless et al., 2002), and/or zircon fertility of the source rock (e.g., Moecher and Samson, 2006; Dickinson, 2008a) rather than the absence of rocks of that age in the source region.

\section{Potential Source Regions for the Hornbrook Formation}

Based on paleocurrent indicators, cobble composition of the Klamath River Conglomerate member, sandstone petrography, and occurrence as an overlap assemblage on the eastern flank of the Klamath Mountains, Nilsen (1993) and others (summarized in Nilsen, 1984) suggested that the Hornbrook Formation sediment was wholly derived from the Klamath Mountains. However, new provenance data presented here require evaluation of all potential source regions for the Hornbrook Formation (Figs. 9 and 10).

Although the Cretaceous configuration of terranes in the North American Cordillera remains 
A
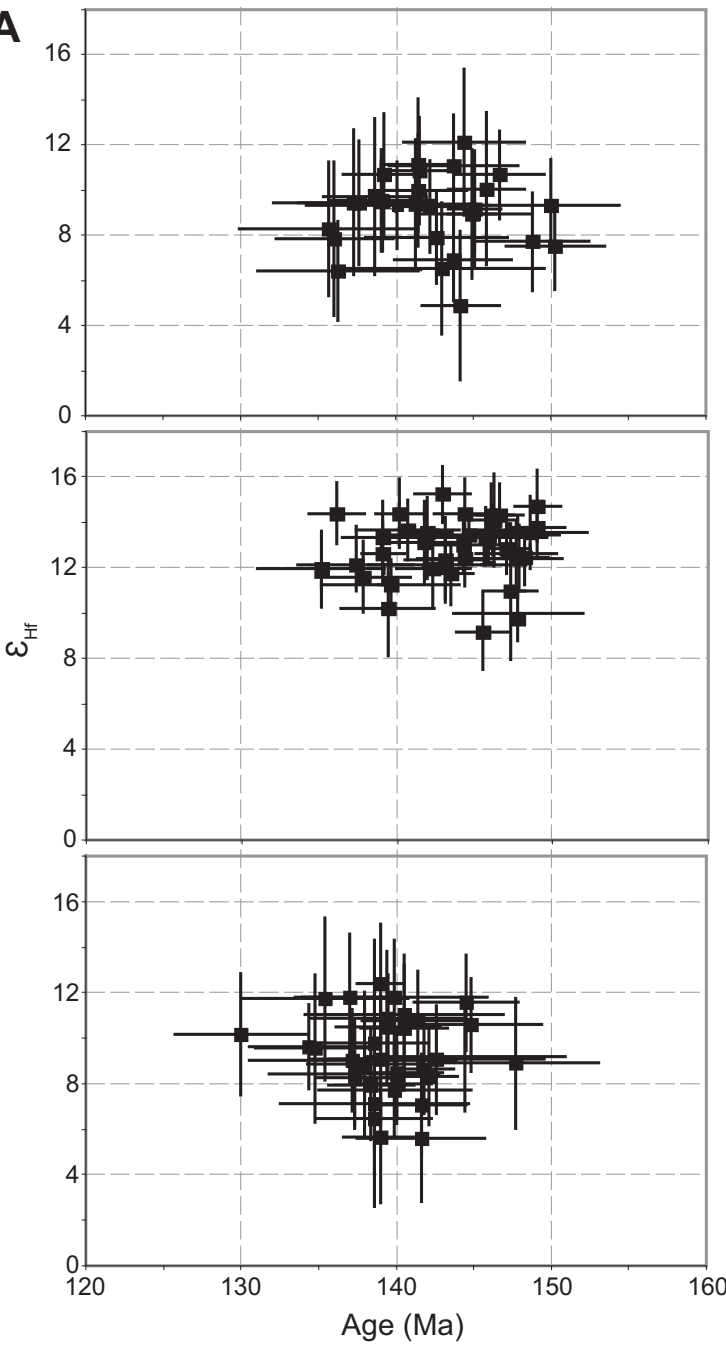

B

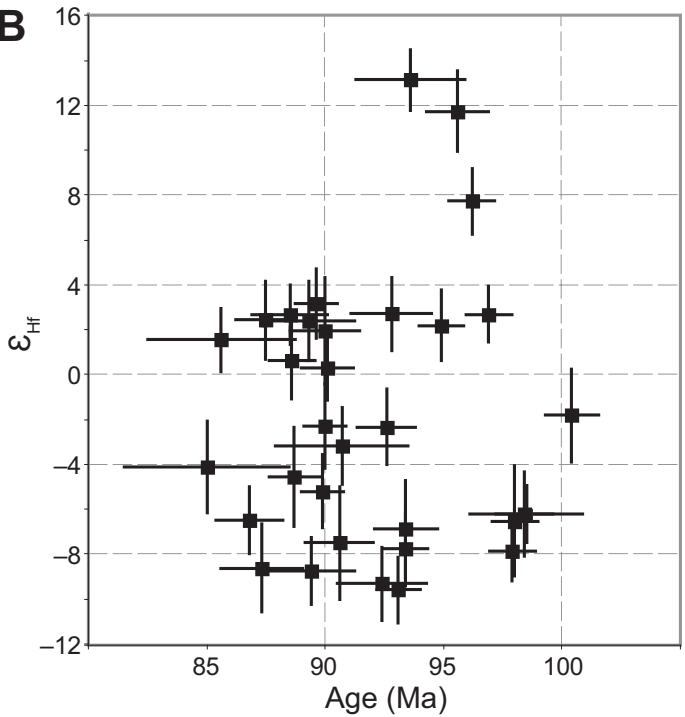

Figure 7. Detrital zircon $\varepsilon_{\mathrm{Hf}}$ versus age plots for selected zircon grains from four sandstone samples, plotted with $2 \sigma$ uncertainties. (A) $\varepsilon_{\mathrm{Hf}}$ for 150-130 Ma detrital zircon in one Klamath River Conglomerate and two Osburger Gulch Sandstone samples. (B) $\varepsilon_{\mathrm{Hf}}$ for 100-85 Ma detrital zircon in one Rocky Gulch Sandstone sample. controversial (e.g., Cowan et al., 1997; Haggart et al., 2006), the Late Cretaceous paleogeography of the California-Oregon region is somewhat better constrained. Proposed Early Cretaceous strike-slip motion in the Great Valley Group (Wright and Wyld, 2007) and Late Jurassic strike-slip motion in the Sierra Nevada Batholith (Lahren and Schweickert, 1994; Grasse et al., 2001) occurred before deposition of the Upper Cretaceous Hornbrook Formation, and the Hornbrook basin lies inboard of proposed translated terranes associated with the Baja British Columbia hypothesis (e.g., Cowan et al., 1997). The Klamath Mountains were displaced westward in Late Jurassic or Early Cretaceous time (Irwin, 1960; Jones and Irwin, 1971; Constenius et al., 2000; Ernst et al., 2008; Batt et al., 2010a), such that the current configuration between the Sierran Foothills belt and correlative units in the Klamath Mountains was established prior to deposition of the Hornbrook Formation (Fig. 9).
Figure 8. $\varepsilon_{\mathrm{Nd}}$ versus depositional age for Hornbrook Formation and Great Valley Group (GVG) samples (GVG data from Linn et al., 1991). Range of Sierran $\varepsilon_{\mathrm{Nd}}$ values is indicated in light-gray shading (values from DePaolo, 1981). Hornbrook Formation samples are shown with $1 \sigma$ uncertainty.

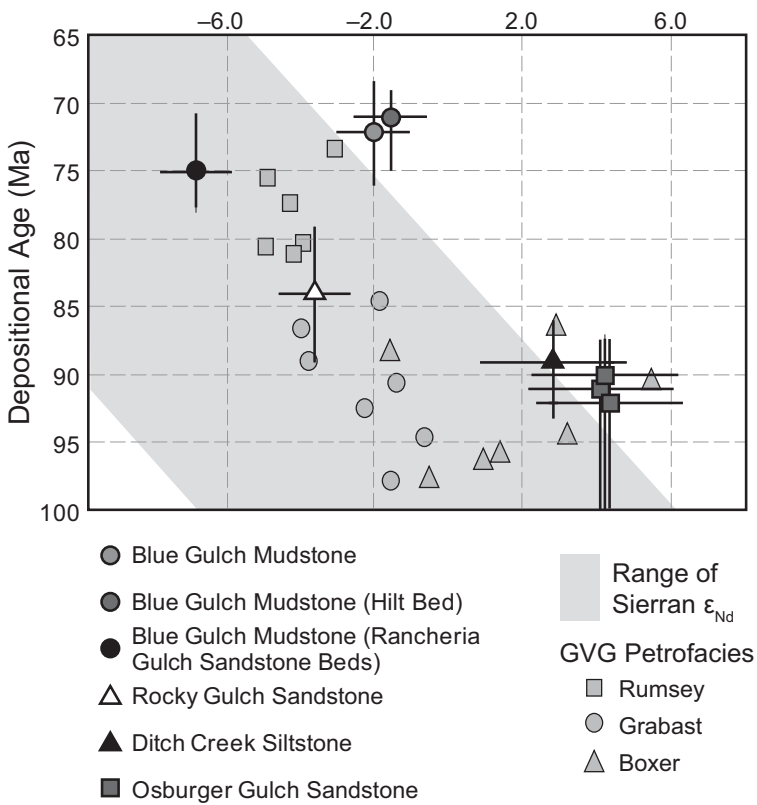

Osburger Gulch Sandstone

Grabast 


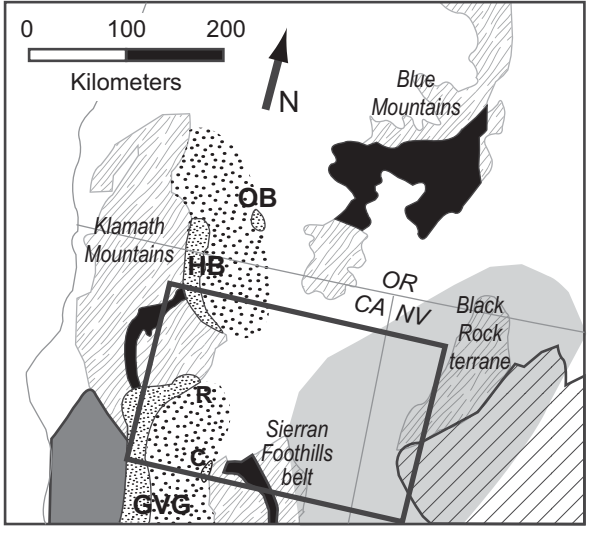

Approximate outcrop limits (dense stipple) and possible extent (diffuse stipple) of Upper Cretaceous forearc basins

Approximate extent of the Cretaceous Sierra Nevada Arc

Cretaceous subduction complex (melanges and blueschists)

Late Paleozoic-Early Mesozoic subduction complex assemblages

Paleozoic-Early Mesozoic volcanic arc assemblages (including Mesozoic plutons)

Paleozoic eugeoclinal assemblages

Approximate area of block diagrams (Figure 11)

Figure 9. Schematic reconstruction of paleogeography during the time of Hornbrook Formation deposition. Following Wyld et al.'s (2006) reconstruction, post-Cretaceous rotation of the Blue Mountains has been restored, bringing the related Ochoco Basin (OB) into the region of Hornbrook deposition, and forming the postulated Hornbrook-Ochoco (H-O) basin. Extent of Cretaceous Sierran magmatism is based on paleogeographic map of Van Buer et al. (2009). Stippled pattern indicates the approximate extent of the Hornbrook basin (HB) and Great Valley Group (GVG) to the south, and box outline indicates the approximate area of the block diagrams shown in Figure 11.

The Blue Mountains Province in central and eastern Oregon has undergone $60^{\circ}$ of clockwise rotation since Jurassic time (Wilson and Cox, 1980; Mankinen, 1984; Mankinen and Irwin, 1990), and $37.5^{\circ} \pm 9.6^{\circ}$ of rotation since Albian time (Housen and Dorsey, 2002). In their 100 Ma reconstruction, Wyld et al. (2006) held the eastern edge of the Blue Mountains Province fixed relative to North America, as required by $110-90 \mathrm{Ma}$ intrusions of the western Idaho shear zone (Manduca et al., 1993; Snee et al., 1995), while restoring the rest of the province $38^{\circ}$ counterclockwise. Moreover,
Wyld et al. (2006) restored $\sim 50 \mathrm{~km}$ of shortening and $40 \mathrm{~km}$ of dextral offset in the western Idaho shear zone, shifting the Blue Mountains Province west and south. As a result, the Blue Mountains Province restores to a position adjacent to the Hornbrook Formation at $100 \mathrm{Ma}$, and provides a potential source of east-derived sediment (Fig. 9). Terranes of the Blue Mountains Province include Paleozoic and early Mesozoic island-arc and subduction-accretion assemblages that are unconformably overlain by Triassic-Jurassic clastic deposits (Fig. 10; Dickinson and Thayer, 1978; Dorsey and LaMaskin, 2007; LaMaskin et al., 2008). The Blue Mountains contain Triassic-Lower Jurassic (238-187 Ma; Northrup et al., 2011), Upper Jurassic (162-150 Ma), and Lower Cretaceous igneous rocks (148-141 Ma and 124-111 Ma; Walker, 1995; Anderson et al., 2011; Schwartz et al., 2011), as well as Triassic and Jurassic clastic strata that contain abundant Precambrian detrital zircons (LaMaskin et al., 2008, 2011). Two 153-150 Ma plutons yield very positive $\varepsilon_{\mathrm{Hf}}$ values, ranging from +16 to +10 , and four 148 $146 \mathrm{Ma}$ plutons have slightly less positive $\varepsilon_{\mathrm{Hf}}$ values, which range from +14 to +4 (Anderson et al., 2011). Late Jurassic contractional deformation in the Blue Mountains Province affected late Middle Triassic to early Late Jurassic sedimentary rocks (Avé Lallemant, 1995; LaMaskin et al., 2011; Schwartz et al., 2011). Therefore, if the Blue Mountains remained a topographic high that shed sediment to the west and northwest during Cretaceous time, any catchment area would likely include these widespread sedimentary units, and resulting detrital zircon grains would reflect derivation from both plutonic sources and recycled sedimentary sources.

The Idaho Batholith is a largely Late Cretaceous intrusive complex with most magmatism younger than $85 \mathrm{Ma}$, and up to $120 \mathrm{Ma}$ magmatism recorded along its western and northwestern margins (Fig. 10; Lewis et al., 1987). Recent $\mathrm{U}-\mathrm{Pb}$ geochronology of the Idaho Batholith revealed an early metaluminous suite of plutons that are 98-85 Ma in age (Gaschnig et al., 2010 ), with $\varepsilon_{\mathrm{Hf}}$ values that range from -6 to -12 (Gaschnig et al., 2011). Many of these Cretaceous zircon crystals in the Idaho Batholith contain Precambrian cores (Gaschnig et al., 2010).

The Black Rock terrane of northwestern Nevada includes Triassic and Jurassic volcanic arc successions that formed part of the continental margin or fringing arc system of the western U.S. Cordillera (Davis et al., 1978; Burchfiel et al., 1992; Wyld, 1996). The Pine Forest Range, Jackson Mountains, and Bilk Creek Mountains expose a Paleozoic arc system overlain by Triassic to Lower Jurassic arc-derived strata and intruded by Jurassic and Lower Cretaceous plu- tons (Fig. 10; Jones, 1990; Wyld, 1990, 1996). $\mathrm{Pb}-\mathrm{Pb}$ and $\mathrm{U}-\mathrm{Pb}$ zircon ages from plutons in the Pine Forest Range are 201-185 Ma (Wyld, 1996), and plutons in the Jackson Mountains are 196-190 Ma and 170-163 Ma (Quinn et al., 1997). A major Jurassic-Cretaceous unconformity records an episode of uplift that resulted in the erosion of most of the supracrustal strata of the Early Jurassic volcanic system (Quinn et al., 1997; Martin et al., 2010). $\mathrm{Pb}-\mathrm{Pb}$ age dates of 125 and 123 Ma were determined from a crosscutting intrusion and an ash-flow tuff interbedded with well-stratified Lower Cretaceous sedimentary rocks in the Jackson Mountains (Quinn et al., 1997).

The Klamath Mountains consist of a series of accreted terranes that include abundant mafic volcanic and plutonic rocks, chert-argillite-limestone units, metasedimentary rocks, fine-grained clastic strata, and ophiolites (Fig. 10; e.g., Irwin, 1960, 1981; Burchfiel et al., 1992; Saleeby et al., 1992; Snoke and Barnes, 2006; Dickinson, 2008b; Ernst et al., 2008). Intermediate to felsic igneous rocks in the Klamath Mountains intruded as discrete plutons, stocks, and small batholiths in distinct periods during the Early Jurassic (ca. $200 \mathrm{Ma}$ ), Early-Middle Jurassic (177-167 Ma), Late Jurassic (161-155 Ma), and latest Jurassic to Early Cretaceous (150-136 Ma; Hacker et al., 1995; Irwin and Wooden, 1999, and references therein; Allen and Barnes, 2006). Whole-rock $\varepsilon_{\mathrm{Nd}}$ values for Jurassic and Cretaceous plutons (170-136 Ma) in the Klamath Mountains range from +2.0 to +8.2 (Barnes et al., 1992; Allen and Barnes, 2006). The $\varepsilon_{\mathrm{Hf}}$ analysis of zircon collected from three Early Cretaceous (136$139 \mathrm{Ma}$ ) plutons in the Klamath Mountains revealed positive $\varepsilon_{\mathrm{Hf}}$ values that range from +5 to +15 (Todt et al., 2011).

The separation of the Klamath Mountains from the once-contiguous Sierra Nevada Mountains was likely accommodated through extension (Batt et al., 2010a) with a component of sinistral strike-slip motion (Ernst et al., 2008). Thermochronologic study of the Western Klamath Mountains suggests that this separation of the Klamath Mountains from the Sierra Nevada was followed by Early Cretaceous (late Valanginian to late Hauterivian) burial of the western Klamath region that peaked prior to $115 \mathrm{Ma}$, with sedimentation thicknesses locally reaching $5.4 \mathrm{~km}$ while local paleohighs within this Lower Cretaceous basin received little to no sedimentary cover (Batt et al., 2010a). Rapid cooling related to exhumation of as much as $12 \mathrm{~km}$ of the western Klamaths region between 115 and 105 Ma resulted in erosion of Early Cretaceous sediments as well as underlying crystalline basement rocks (Batt et al., 2010a). 
Figure 10. Simplified tectonostratigraphic cartoon showing major Mesozoic accretionary belts, arc assemblages, plutons, and sedimentary overlap sequences for each of the potential source regions for the Hornbrook Formation. Blue Mountains terrane stratigraphy is redrawn from LaMaskin et al. (2008); pluton ages are from Walker (1995), Schwartz et al. (2011), and Anderson et al. (2011); Idaho Batholith ages are from Gaschnig et al. (2010); Black Rock terrane age data are from Jones (1990), Wyld (1990), Wyld et al. (1996), and Quinn et al. (1997); and Klamath Mountains and Sierra Nevada (SN) terrane stratigraphy is redrawn from Dickinson (2008b).

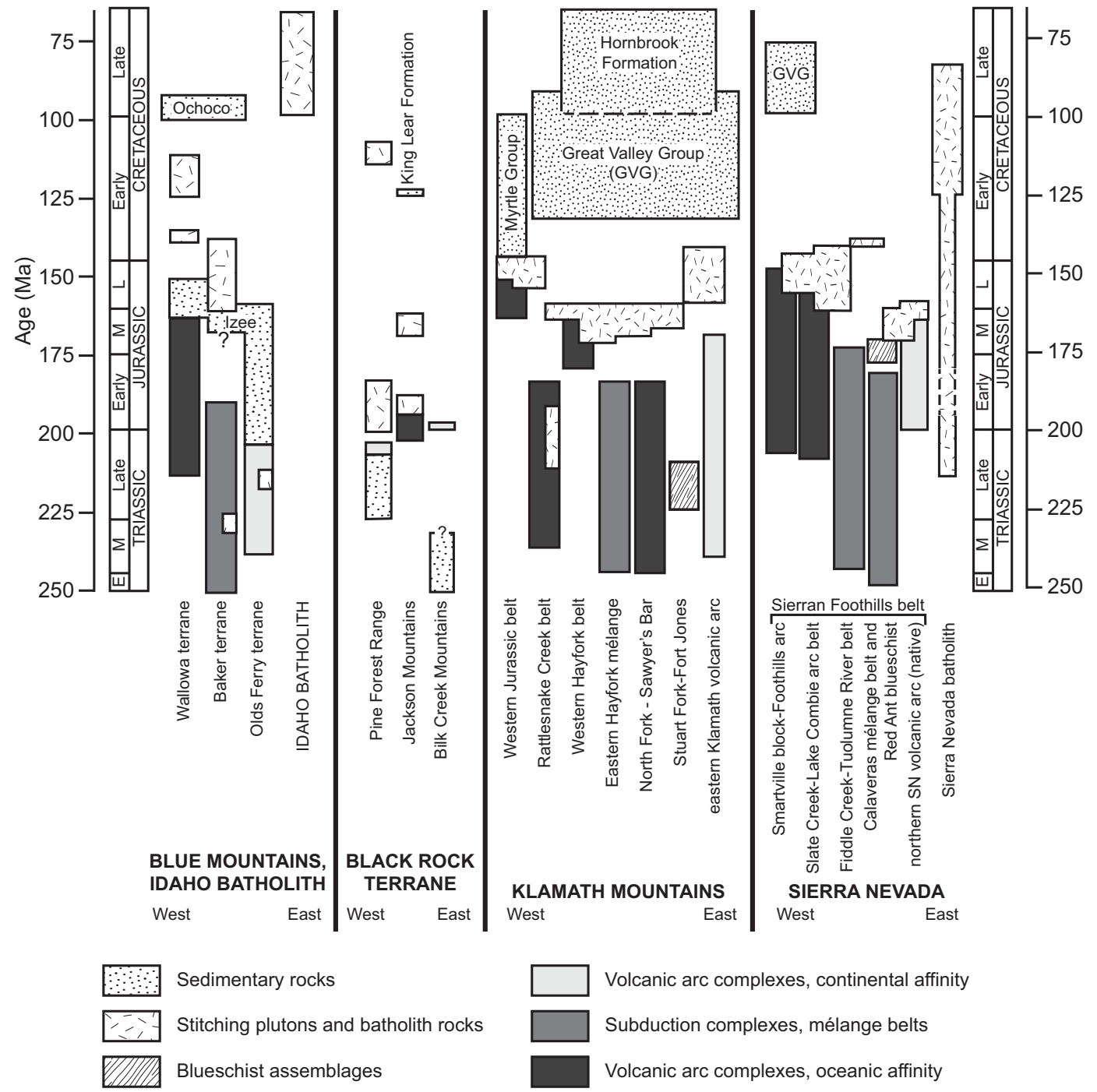

Thermochronology of Early Cretaceous plutons in the Eastern Klamath Mountains also indicates a period of Cretaceous exhumation due to top-to-the-south extension along the Trinity detachment surface that continued until ca. $80 \mathrm{Ma}$ (Batt et al., 2010b). Present surface exposures of Early Cretaceous plutons in the footwall block of the Trinity detachment fault were exhumed from their emplacement depths of 7-10 km to within $<4 \mathrm{~km}$ of the surface during this Cretaceous extension (Batt et al., 2010b).

Lithotectonic belts of the Sierran Foothills terranes form a complex assemblage of Paleozoic and early Mesozoic arc-related terranes and subduction complexes, and are composed of serpentinized ultramafic rocks, blueschists, chert-argillite-limestone mélange, metasedimentary rocks, and ophiolites (Fig. 10; Miller et al., 1992, and references therein; Snow and Scherer, 2006; Ernst et al., 2008). These accretionary belts were intruded by plutonic rocks at
205-200 Ma, 173-155 Ma, 142-136 Ma, and $133 \mathrm{Ma}$ (Irwin, 2003, and references therein). The $\varepsilon_{\mathrm{Hf}}$ analysis of zircon collected from two Early Cretaceous (138 Ma) plutons in the Foothills arc revealed positive $\varepsilon_{\mathrm{Hf}}$ values that range from +7 to +19 (Todt et al., 2011).

The Sierra Nevada Batholith consists of plutons that intruded the North American margin in Jurassic and Cretaceous time (e.g., Evernden and Kistler, 1970; Stern et al., 1981; Bateman, 1983; Saleeby et al., 1989). The main Cretaceous batholith of the Sierra Nevada Mountains is 125-82 Ma in age (Chen and Moore, 1982; Bateman, 1992; Irwin, 2003), with a magmatic flare-up between 100 and $85 \mathrm{Ma}$ that accounted for $78 \%$ of the magmatic volume of the California arc (Ducea, 2001). DePaolo (1981) measured $\mathrm{a}+6.5$ to -7.6 range of $\varepsilon_{\mathrm{Nd}}$ values for plutonic rocks of the Sierra Nevada Batholith. The $\varepsilon_{\mathrm{Hf}}$ values measured in 121-103 Ma zircon from the central and western Sierra Nevada
Batholith range from +3.9 to -6.9 and become more negative with time (Lackey et al., 2010), but additional Hf data for younger Sierra Nevada Batholith rocks are not yet available. Van Buer et al. (2009) noted that after removing Cenozoic cover rocks and extension, the Sierra Nevada Batholith appears to have been continuous across northwestern Nevada during the Cretaceous, trending north-northeast and intruding older, backarc basin deposits (Fig. 9). The nowburied northwestern edge of the Cretaceous batholith has been imaged seismically in northwest Nevada (Lerch et al., 2007).

\section{Hornbrook Formation Provenance}

Detrital zircon age distributions in the Klamath River Conglomerate are consistent with provenance in the Klamath Mountains and/or the Sierran Foothills belt. Both potential source regions contain Middle Jurassic and Early 
Figure 11. Cartoon block diagrams illustrating depositional environment and interpreted source regions for each member of the Hornbrook Formation; view is to the south, with the area represented indicated by a black rectangle in Figure 9. Question marks indicate uncertainty in the sedimentation details of the eastern margin of the Hornbrook-Ochoco basin as well as the extent of Klamath Mountains subsidence in the latest Cretaceous; dashed line marks approximate location of shelf-slope break. C-Chico area of Great Valley Group; R-Redding area of Great Valley Group; BRT-western extent of Black Rock terrane. Deposition in western outcrop belt of Great Valley Group is not shown in this diagram.

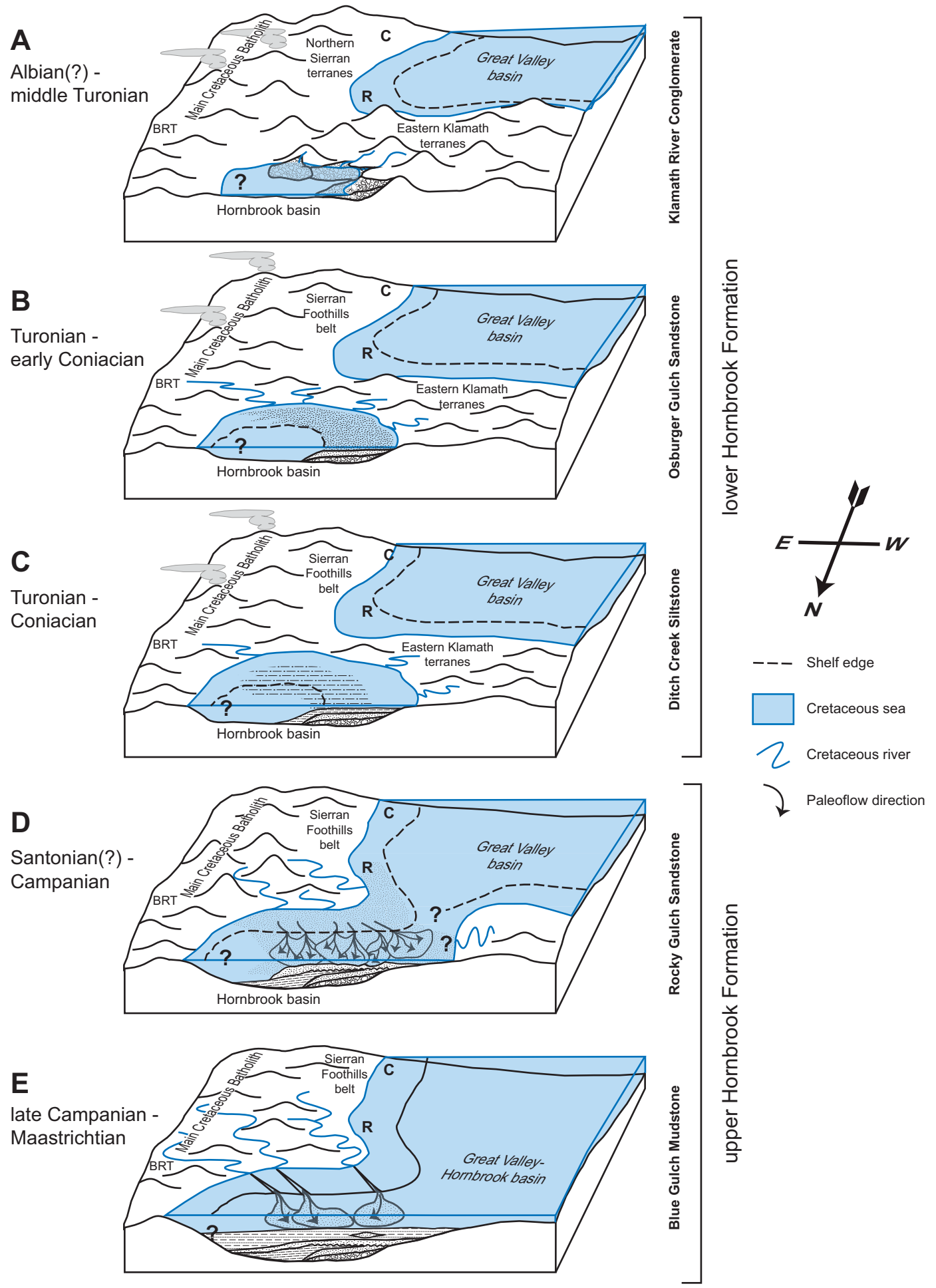

Cretaceous plutons, and the positive $\varepsilon_{\mathrm{Hf}}$ values from Early Cretaceous detrital zircon (range of +6 to +12 ) overlap with $\varepsilon_{\mathrm{Hf}}$ values measured in Early Cretaceous plutons in both regions $(+5$ to +19 ). Late Jurassic to Early Cretaceous plutons in the Blue Mountains Province also contain positive $\varepsilon_{\mathrm{Hf}}$ values (+16 to +4$)$, and the $141 \mathrm{Ma}$ age of the Wallowa Batholith of the Blue Mountains Province matches well with the $141 \mathrm{Ma}$ peak in the southern Klamath River Conglomerate sample (06-KS-04; Fig. 5). However, the Blue Mountains Province does not include the entire range of ages present in the detrital signature, and likely includes a significant propor- tion of recycled Paleozoic and Precambrian ages (LaMaskin et al., 2011) that are not present in the Klamath River Conglomerate. Plutons in the Black Rock terrane are older than ages present in the Klamath River Conglomerate, and the Idaho Batholith and main Cretaceous Sierran Batholith are both too young. 
Precambrian ages obtained from quartzite cobbles in the Klamath River Conglomerate (Fig. 6) are typical of a northwestern Laurentian cratonal signature (cf. Grove et al., 2008). These Precambrian age distributions are not unique (LaMaskin, 2012), and match well with detrital ages found in the Antelope Mountain Quartzite of the eastern Klamath terranes (Wallin et al., 2000), quartzose sedimentary rocks in the Eastern Hayfork terrane of the Klamath Mountains (Scherer et al., 2010), and the Shoo Fly complex and overlap assemblage in the Sierran Foothills belt (Harding et al., 2000; Spurlin et al., 2000). Detrital zircon ages in the Blue Mountains Province and the Black Rock terrane also overlap with the Klamath River Conglomerate cobble ages (Darby et al., 2000), but these regions are not characterized by quartzite units and therefore are not considered likely sources here.

Although the detrital zircon age and $\mathrm{Hf}$ results permit Klamath River Conglomerate provenance in either the Klamath Mountains or the Sierran Foothills belt, we prefer a Klamath Mountains source for the following reasons: (1) the fluvial to alluvial depositional environment and angular cobbles in the conglomerate indicate a proximal source, and (2), onlap of the Klamath River Conglomerate on Klamath Mountains basement, sandstone petrography, conglomerate clast compositions, and north- to northeast-directed paleocurrent indicators all suggest a source in the Klamath Mountains (Fig. 11A). Mid-Cretaceous exhumation of the Klamath Mountains due to regional extension (Batt et al., 2010a, 2010b) may have created regional topography within the pre- viously low-lying eastern Klamath terranes that resulted in north-northeast-directed transport and deposition of locally derived conglomerate and sandstone into the newly subsiding Hornbrook basin, as well as significant south-directed transport into the Great Valley forearc basin. A sample obtained from sandstone of the Lower Cretaceous Platina petrofacies (JC04-07) of the northern Great Valley Group contains an age distribution very similar to the southernmost Klamath River Conglomerate sample (06-KS-04); both samples contain a large Early Cretaceous peak at $141 \mathrm{Ma}$ and few Jurassic and Precambrian ages (Fig. 12). As in the Klamath River Conglomerate sample, 135-150 Ma detrital zircon grains in the Platina petrofacies have positive $\varepsilon_{\mathrm{Hf}}$ values that range from +6 to +12 (Todt et al., 2011), similar to the positive $\varepsilon_{\mathrm{Hf}}$ values of Early Cretaceous plutons within the eastern Klamath terrane.

The Osburger Gulch Sandstone member may also have Klamath Mountains and/or Sierran Foothills belt provenance, but it may have received some sediment from additional source regions that were located east and southeast of the Hornbrook basin (Fig. 11B). Like the Klamath River Conglomerate, the Osburger Gulch Sandstone has abundant Early Cretaceous grains with positive $\varepsilon_{\mathrm{Hf}}$ values $(+9$ to +13 ) that match well with plutons in the Klamath Mountains, Sierran Foothills belt, and Blue Mountains Province, but paleocurrent indicators are more varied than in the Klamath River Conglomerate, with sediment transport from the southeast, south, and west (Fig. 3). The whole-rock $\varepsilon_{\mathrm{Nd}}$ values for the Osburger Gulch Sandstone $(+4)$ are slightly more positive than the main Cretaceous Sierran Batholith, but they overlap with values measured in the Boxer petrofacies of the Great Valley Group (Fig. 8), which is interpreted as derived from the Sierran Foothills belt (Ingersoll, 1979, 1983; Linn et al., 1991, 1992; DeGraaff-Surpless et al., 2002) The Osburger Gulch Sandstone member also contains 11 grains that are 87-130 Ma, which are younger than the youngest ages found in the Klamath Mountains (Shasta Bally Batholith; 136 Ma; Lanphere and Jones, 1978) and Sierran Foothills belt (Irwin, 2003). Moreover, all three Osburger Gulch Sandstone samples contain many Early Jurassic zircon grains that do not occur in the Klamath River Conglomerate (Fig. 5). LaMaskin et al. (2011) noted that Early Jurassic plutons are not common in the U.S. Cordillera and concluded that Early Jurassic grains found in Middle and Upper Jurassic strata within the Blue Mountains Province were derived from the Black Rock terrane or recycled through Jurassic erg deposits. The Early Jurassic grains in the Osburger Gulch Sandstone thus may also be derived from the Black Rock terrane. The lack of pre-Mesozoic grains in the Osburger Gulch Sandstone age distributions suggests that these Early Jurassic grains probably were not derived from Jurassic clastic rocks or interbedded volcanic units in the Blue Mountains, nor were they recycled from Jurassic erg deposits. Although it is possible that the Osburger Gulch Sandstone provenance was entirely within the Sierran Foothills belt and areas to the east, paleocurrent
Figure 12. Histograms and superimposed probability density plots of detrital zircon age data for the Klamath River Conglomerate sandstone and the Platina petrofacies of the Great Valley Group. Age distributions are shown at two scales, with the Mesozoic portion of the distribution expanded for ease in comparison.

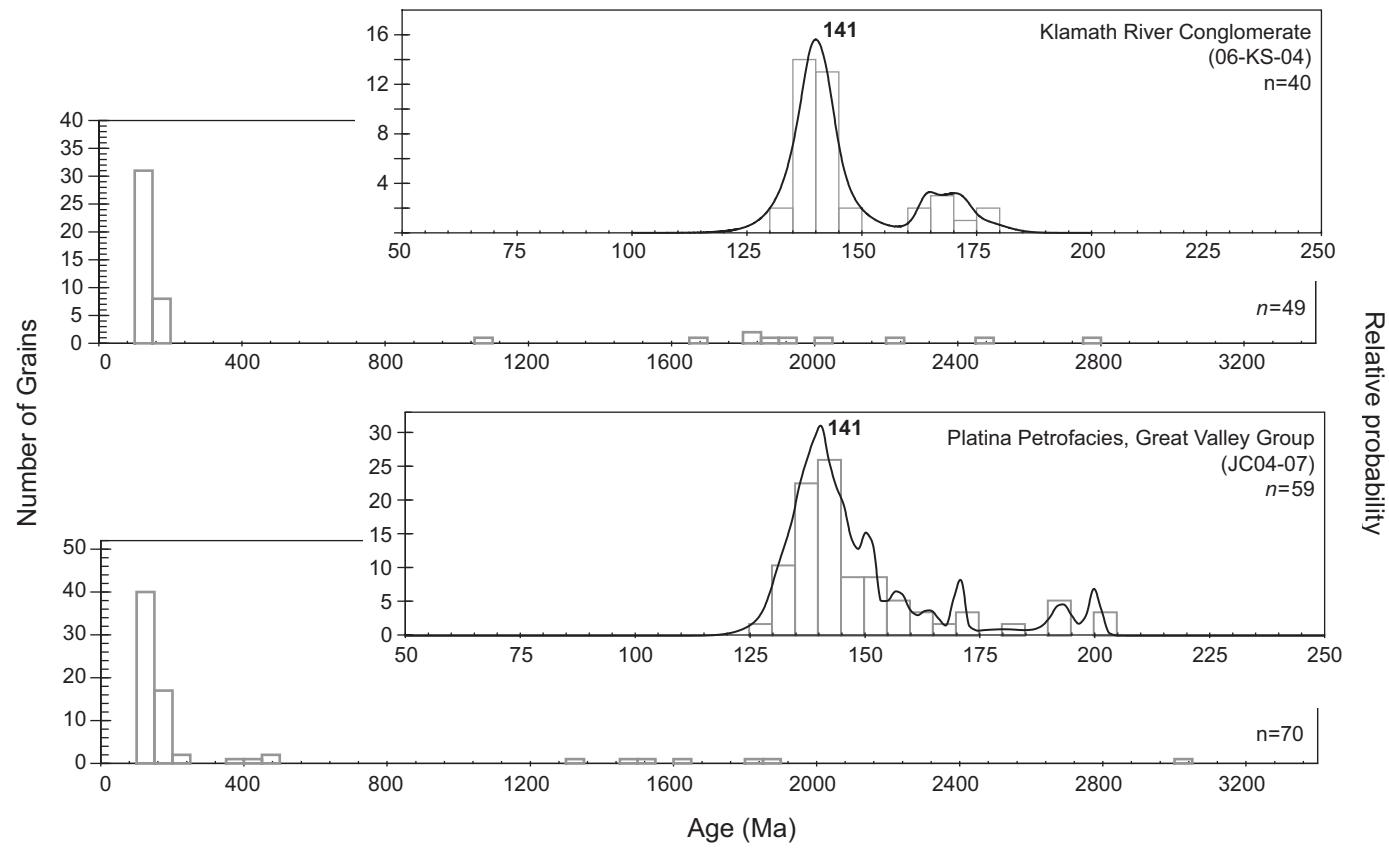

Geological Society of America Bulletin, May/June 2013 
data are consistent with a component of continued input from the Klamath Mountains. Limited data from the Ditch Creek Siltstone member preclude detailed provenance interpretation, but whole-rock $\varepsilon_{\mathrm{Nd}}$ values are positive $(+3)$, similar to those in the underlying Osburger Gulch Sandstone and in the Boxer petrofacies of the Great Valley Group (Fig. 8), and may indicate similar provenance (Fig. 11C).

The Rocky Gulch Sandstone member and the Rancheria Gulch Sandstone Beds in the lowermost Blue Gulch Mudstone member are remarkably similar in their Mesozoic detrital zircon age distributions, and they mark an abrupt shift in age distributions from the lower members of the Hornbrook Formation (Figs. 5 and 6). Cretaceous grains younger than $126 \mathrm{Ma}$ comprise $55 \%$ and $66 \%$ of the Rocky Gulch Sandstone and Rancheria Gulch Sandstone Beds, respectively, and include large Late Cretaceous peaks; in contrast, less than $3 \%$ of grains in the Osburger Gulch Sandstone member are younger than $126 \mathrm{Ma}$, and no grains younger than 133 Ma were found in the Klamath River Conglomerate member. The abundance of Cretaceous grains and the large 85-100 Ma peak in these samples are consistent with a source in the main Cretaceous Sierran Batholith, including the now-buried northeastern extension of the batholith (Figs. 9 and 11D; Van Buer et al., 2009). Paleocurrent data indicate sediment transport from the west, south, and southeast for the Rocky Gulch Sandstone member, and transport from the southeast for the Rancheria Gulch Sandstone Beds (Nilsen, 1993). The Late Cretaceous peak matches the timing of the largest magmatic flux episode in the Cretaceous batholith (Ducea, 2001), and whole-rock $\varepsilon_{\mathrm{Nd}}$ values from the Rocky Gulch Sandstone member and Rancheria Gulch Sandstone Beds plot within the $\varepsilon_{\mathrm{Nd}}$ range of the Sierran Batholith (DePaolo, 1981) and overlap with $\varepsilon_{\mathrm{Nd}}$ values measured in Great Valley Group petrofacies derived from the Sierran Batholith (Fig. 8; Linn et al., 1991, 1992). The 98-85 Ma early metaluminous suite of plutons in the Idaho Batholith (Gaschnig et al., 2010) also matches these Late Cretaceous detrital zircon ages, but we find little evidence of inherited Precambrian cores in the detrital zircon grains, and $\varepsilon_{\mathrm{Hf}}$ values from the $85-100 \mathrm{Ma}$ detrital zircons in the Rocky Gulch Sandstone vary from +13.1 to -9.6 , i.e., more positive than the -6 to $-12 \varepsilon_{\mathrm{Hf}}$ values reported for similar ages in the Idaho Batholith (Gaschnig et al., 2011). Comparable $\varepsilon_{\mathrm{Hf}}$ data for the 100-85 Ma component of the main Cretaceous Sierran Batholith are not yet available.

Middle and Late Jurassic and Early Cretaceous detrital zircon grains in the Rocky Gulch Sandstone and Rancheria Gulch Sandstone
Beds may have been derived from a variety of sources, including the Klamath Mountains, Sierran Foothills belt, and Blue Mountains Province. The relative contributions of these potential sources are difficult to determine, but the presence of east-directed paleocurrent indicators suggests some continued input from the Klamath Mountains.

The Rancheria Gulch Sandstone Beds sample contains abundant Precambrian detrital zircon characterized by two broad peaks at 1300 $1500 \mathrm{Ma}$ and 1600-1800 Ma (Fig. 6). This Precambrian age distribution is distinct from the Precambrian ages found in the Klamath River Conglomerate member quartzite cobbles and sandstone sample, which are characterized largely by grains older than $1800 \mathrm{Ma}$ (Fig. 6), and does not match well with terranes in the Klamath Mountains and Sierran Foothills belt. The upper Hornbrook Precambrian age distribution is typical of southwestern Laurentian sources (cf. Grove et al., 2008), and the best match for these Precambrian ages may be in the Nevada portion of the Cordilleran miogeocline (Gehrels and Dickinson, 1995) or in the Black Rock terrane (Darby et al., 2000). The Rocky Gulch Sandstone sample contains only two Precambrian grains; both grains fall within the 1300-1500 Ma peak in the Rancheria Gulch Sandstone Beds sample (Fig. 6).

The two Blue Gulch Mudstone member samples from above the Rancheria Gulch Sandstone Beds record a reduction and then loss of the 100-85 Ma peak, complete absence of 130-155 Ma grains, and a return of the Early Jurassic detrital zircon. Sparse paleocurrent indicators in the Blue Gulch Mudstone member indicate sediment transport from the southeast, south, southwest, and west (Nilsen, 1993). The Early Jurassic grains suggest a return to a source in the Black Rock terrane, and the Middle to Late Jurassic (175-155 Ma) and Early Cretaceous (120-100 Ma) grains could be derived from plutons in the Klamath Mountains or Sierran Foothills belt, and Blue Mountains Province. However, the Late Jurassic to Early Cretaceous ages (150-130 Ma) that characterize the Klamath Mountains and Sierran Foothills belt, as well as Great Valley Group strata derived from these terranes (DeGraaff-Surpless et al., 2002), are completely absent in the Blue Gulch Mudstone samples, as are significant preMesozoic ages that would be expected if zircon grains were derived from Blue Mountains strata (LaMaskin et al., 2011). Given the continued presence of grains younger than $125 \mathrm{Ma}$, as well as $175-200 \mathrm{Ma}$, we favor derivation of the Blue Gulch Mudstone member from multiple sources in the Black Rock terrane and Sierran Batholith to the east and southeast of the Hornbrook basin
(Fig. 11E). The whole-rock $\varepsilon_{\mathrm{Nd}}$ values ( - 2) for these two Blue Gulch Mudstone samples are slightly more positive than the Sierran Batholith $\varepsilon_{\mathrm{Nd}}$ range, but still more negative than Klamath Mountains values ( +2 to +8 ) or the lower Hornbrook samples $(+3$ to +5$)$, and they may reflect the result of mixing multiple sediment sources in the Hornbrook basin. The few Precambrian grains fall between 1100 and $1200 \mathrm{Ma}$ and ca. $1700 \mathrm{Ma}$, but they are not abundant enough to form robust age peaks for more detailed provenance interpretation.

\section{Tectonic Implications of Hornbrook Formation Provenance}

Our new provenance data record changing sediment sources for the Hornbrook Formation and demonstrate that the Klamath Mountains could not have been the only or even primary sediment source for most of the Hornbrook Formation members. In fact, only the Klamath River Conglomerate member could have been derived solely from the Klamath Mountains. Lower Jurassic detrital zircons are abundant in the Osburger Gulch Sandstone and the Blue Gulch Mudstone member, and are present in all but the Klamath River Conglomerate, requiring addition of a non-Klamath source of sediment by the time of Osburger Gulch Sandstone deposition.

A striking provenance shift occurred between the Osburger Gulch Sandstone and the Rocky Gulch Sandstone with the introduction of abundant Late Cretaceous detrital zircon grains and an abrupt reduction in the number of previously abundant Late Jurassic-Early Cretaceous grains. This provenance change is also recorded by whole-rock $\varepsilon_{\mathrm{Nd}}$ values that are positive +4.3 to +2.7 in the Osburger Gulch and Ditch Creek Siltstone samples, and more negative $(-1.7$ to -6.9 ) in the Rocky Gulch Sandstone and Blue Gulch Mudstone members. The lower three members of the Hornbrook Formation (Klamath River Conglomerate, Osburger Gulch Sandstone, and Ditch Creek Siltstone, herein collectively referred to as the lower Hornbrook Formation) record significant Klamath Mountains and possibly Sierran Foothills belt sources with increasing southeastern/eastern input from the Black Rock terrane through early Late Cretaceous time (Figs. 5 and $11 \mathrm{~A}-11 \mathrm{C}$ ). Provenance shifted in middle Late Cretaceous time to almost entirely eastern and southeastern sources for the upper two members of the Hornbrook Formation (Rocky Gulch Sandstone and Blue Gulch Mudstone, herein collectively referred to as the upper Hornbrook Formation; Figs. 5 and 11D-11E). The Ditch Creek Siltstone was deposited in Turonian to Coniacian time, and the depositional age of the Rocky Gulch Sand- 
stone is uncertain and may be Santonian to late Campanian, but the overlying Rancheria Gulch Sandstone Beds of the Blue Gulch Mudstone member are late Campanian. Thus, the provenance shift occurred sometime during Turonian to late Campanian time (93.5-70.5 Ma).

The timing of this provenance shift coincides with the intrabasinal unconformity mapped in the Hornbrook Basin based on an erosional contact between the Ditch Creek Siltstone and Rocky Gulch Sandstone members in the type area of the Hornbrook Formation (Peck et al., 1956; Elliott, 1971), suggesting that this unconformity may be regional in scale and may have resulted from reconfiguration of the basin and its sources at this time. This intrabasinal unconformity spanned as much as late Coniacian to middle Campanian time (ca. 87-77 Ma) in the type section (Elliott, 1971), although Nilsen (1993) observed that the two members appear to be in gradational contact north and south of the Hornbrook type area.

Although the timing of this provenance shift is poorly constrained, it overlaps with the timing of significant tectonic and magmatic changes in the U.S. Cordillera. Mid-Early Cretaceous extension is documented in the Klamath Mountains (Batt et al., 2010a, 2010b), Sierran Foothills belt (Boehlke and Kistler, 1986), and western outcrop belt of the Great Valley Group (Moxon, 1990; Constenius et al., 2000). Thus, footwall exhumation of the Eastern Klamath Mountains and Sierran Foothills belt along normal faults, combined with subsidence in the developing Hornbrook basin, likely controlled the provenance of the lower Hornbrook Formation. In contrast, changing plate interactions during the early Late Cretaceous may have led to contraction and uplift in eastern and southeastern sources beginning at ca. $90 \mathrm{Ma}$. With shallowing of the subducting Farallon slab to near horizontal (e.g., Saleeby, 2003; Dickinson, 2004; Liu et al., 2008), magmatism in the Sierran arc ceased by $82 \mathrm{Ma}$ (Stern et al., 1981; Chen and Moore, 1982), and a peraluminous magmatic flux event occurred in the Idaho Batholith from 80 to $67 \mathrm{Ma}$ (Gaschnig et al., 2010). Inverse mantle convection modeling predicts that Farallon slab flattening began at ca. $90 \mathrm{Ma}$ and resulted in a zone of surface compression in the region of the northern Sierra Nevada and northern Nevada from 80 to $65 \mathrm{Ma}$ (Liu et al., 2008). He zircon data document a rapid midCretaceous exhumation event from 92 to $88 \mathrm{Ma}$ in the western and axial Sierra Nevada Batholith that is also recorded in the eastern Great Valley (Saleeby et al., 2010), consistent with previously documented changing plate kinematics at ca. $90 \mathrm{Ma}$ (Engebretson et al., 1985; Renne et al., 1993; Tobisch et al., 1995). Finally, dextral strike-slip faulting began to dissect the Cordillera at ca. $85 \mathrm{Ma}$, following the separation of the obliquely subducting Kula plate from the Farallon plate and its subsequent rapid northward motion (e.g., Engebretson et al., 1985; Wyld et al., 2006). We suggest that Late Cretaceous contraction and uplift shifted the source of sediment to the east and southeast, tapping into the main Cretaceous batholith and potentially the Black Rock terrane during deposition of the upper Hornbrook Formation. The shorter lag time between the youngest zircon crystallization ages and depositional ages for the upper Hornbrook Formation (compared with the lower Hornbrook Formation) is consistent with rapid exhumation and erosion of eastern sources and concomitant sediment input to the Hornbrook basin.

The part of the main Cretaceous Sierra Nevada Batholith closest to the Hornbrook basin would have been the now-buried northeastern extension of the Cretaceous batholith described by Van Buer et al. (2009) in northwestern Nevada. Our provenance results support paleogeographic reconstructions that extend the Sierran Batholith to the northeast (Fig. 9; Van Buer et al., 2009) and suggest that it was elevated and shedding sediment to the west and northwest during Late Cretaceous time (Figs. 11D and 11E). As this Late Cretaceous source of sediment was eroded following rapid 92-88 Ma exhumation, sediment derived from the Black Rock terrane, including Precambrian detrital zircon grains, increased in relative abundance in the uppermost Hornbrook Formation, producing abundant Precambrian ages in the Rancheria Gulch Sandstone Beds and the return of Early Jurassic zircon grains in the upper two samples of the Blue Gulch Mudstone. The continued presence of Late Cretaceous and Early Jurassic detrital zircons, combined with the absence of Late Jurassic/Early Cretaceous zircons, in the uppermost Hornbrook Formation suggests that there was no return to Klamath Mountains sources (Fig. 11E).

\section{A Single Hornbrook-Great Valley Basin}

Paleocurrent indicators in the Hornbrook and Great Valley Basins suggest that the Eastern Klamath Mountains formed a paleohigh that separated these depocenters (Figs. 11A-11C) and shed sediment both north and south into the two basins. The Hornbrook Formation and the Great Valley Group may have shared a similar Klamath Mountains source during deposition of the lower Hornbrook Formation during latest Early Cretaceous and early Late Cretaceous time (Albian to Turonian-Coniacian), but they were not part of a single basin. The southern Klamath River Conglomerate sandstone sample is remarkably similar to the Platina petrofacies Great Valley Group sample (Fig. 12), and detrital zircon age distributions from the lower Hornbrook Formation and the Great Valley Group samples from the western outcrop belt of the Sacramento Valley both contain abundant Middle to Late Jurassic and Early Cretaceous grains (DeGraaff-Surpless et al., 2002, their fig. 5). Whole-rock $\varepsilon_{\mathrm{Nd}}$ values from Cenomanian-Turonian Great Valley Group (Boxer petrofacies) resulted from derivation in the Klamath Mountains and Sierran Foothills belt (Linn et al., 1991, 1992), and DeGraaff-Surpless et al. (2002) suggested that a drainage divide within the Sierran Foothills belt limited Boxer petrofacies provenance to proximal, western sources. A Klamath Mountains source may also be indicated by the whole-rock $\varepsilon_{\mathrm{Nd}}$ values from the lower Hornbrook Formation, which overlap the Boxer petrofacies $\varepsilon_{\mathrm{Nd}}$ values (Fig. 8).

Provenance data from both the Hornbrook Formation and Great Valley Group record a shift in provenance signatures during the Late Cretaceous, and the previously separate basins may have become integrated during this time (Figs. 11D and 11E). As in the Hornbrook Formation, grains younger than $125 \mathrm{Ma}$ become abundant only in the Coniacian and younger Great Valley Group (Sites and Guinda Formations in the Cache Creek Section of the western outcrop belt; Frazier Siltstone and Bear Creek Sandstone in the Redding Section; and Ten Mile member of the Chico Section; DeGraaffSurpless et al., 2002, their fig. 5). Thus, lag times between zircon crystallization and depositional age are much shorter in the Coniacian and younger Great Valley Group ( $<10$ m.y. lag time) than in the Cenomanian-Turonian Great Valley Group (>40 m.y. lag time). Within the Great Valley Group, only the Santonian to Campanian Guinda Formation in the Cache Creek section and the Coniacian Frazier Siltstone in the Redding section contain abundant Early Jurassic grains; very few Early Jurassic grains were found in the Chico section (DeGraaff-Surpless et al., 2002).

As erosion of the western and axial Sierra Nevada followed rapid uplift at ca. $90 \mathrm{Ma}$ and the main Cretaceous batholith experienced contractional tectonics through $78 \mathrm{Ma}$ (Tobisch et al., 1995), regions further east, such as the Black Rock terrane, may have remained elevated in Coniacian time and perhaps continuing into late Campanian time. Drainage systems and therefore sediment sources for both the Hornbrook Formation and the Great Valley Group would have extended into these elevated eastern sources (Figs. 11D and 11E). In the Hornbrook Formation, the shift from localized sediment sources in the Klamath Mountains and Sierran 
Foothills belt to widely distributed sources that included the main Cretaceous batholith is manifested in the appearance of Late Cretaceous detrital zircons derived from these newly uplifted eastern sources, and the reduction and disappearance of Late Jurassic-Early Cretaceous zircons that characterize sediment derived from Klamath-Sierran Foothills belt sources. In the Great Valley Group, source areas also expanded from relatively localized catchments in the Klamath Mountains and Sierran Foothills belt to include the main Cretaceous batholith farther east (DeGraaff-Surpless et al., 2002); even Early Jurassic grains from the Black Rock terrane may have reached the Great Valley Group in the Redding and Cache Creek areas.

The Hornbrook Formation has been considered the northern extension of the Cretaceous Great Valley Group forearc basin (Nilsen, 1984; Miller et al., 1992), and both basins responded to Late Cretaceous tectonic events. The results of our provenance analysis suggest that the two basins shared a similar source in the Klamath Mountains in early Late Cretaceous time, but were not linked into a single depositional system until Santonian time, when sediment sources for both basins shifted to the east, concomitant with uplift in eastern sources and continued subsidence and relative sea-level rise in the expanding Hornbrook-Great Valley forearc basin.

\section{CONCLUSIONS}

Our detailed provenance analysis of the Hornbrook Formation generates a new picture of an evolving Hornbrook basin that received sediment from the east and southeast as it deepened, and was likely connected to the Great Valley Basin to the south during deposition of the upper Hornbrook members. Significant provenance shifts within the Late Cretaceous Hornbrook Formation and the Great Valley Group may record changing plate interactions as the Farallon slab angle decreased and magmatism and deformation shifted inland. These new provenance results improve reconstructions of Late Cretaceous paleogeography in Oregon and northern California, a region critical to our understanding of Cordilleran paleogeography (e.g., Wyld et al., 2006), and add to the limited data available regarding Cretaceous and older geology below the Cenozoic cover in southeast Oregon and northwest Nevada. Finally, this study of the Hornbrook Formation provides baseline information that can be used to compare with coeval sedimentation in other basins that may have undergone extensive translation, or to test tectonic models that place Cretaceous basins in new configurations and imply new correlations between them.

\section{ACKNOWLEDGMENTS}

The authors wish to thank George Gehrels, Victor Valencia, Mark Pecha, and Nicky Geissler for their assistance with detrital zircon U-Pb and Lu-Hf data collection and processing, as well as their hospitality at the LaserChron Center, and we gratefully acknowledge National Science Foundation (NSF) grant EAR1032156 for support of the Arizona LaserChron Center. We thank Jeff Vervoort at Washington State University for completing the Sm-Nd analysis of our samples. We also wish to thank Greg Augsburger for his assistance in the field and with sample preparation. This manuscript was much improved by thoughtful reviews from Todd LaMaskin, Rebecca Dorsey, Kenneth Ridgway, and Jim Wright. This research was funded by ACS-PRF grant 45737-B8 awarded to Surpless and NSF grant EAR Integrative and Collaborative Education and Research (ICER) 846695 awarded to Surpless.

\section{REFERENCES CITED}

Allen, C.M., and Barnes, C.G., 2006, Ages and some cryptic sources of Mesozoic plutonic rocks in the Klamath Mountains, California and Oregon, in Snoke, A.W., and Barnes, C.G., eds., Geological Studies in the Klamath Mountains Province, California and Oregon; A Volume in Honor of William P. Irwin: Geological Society of America Special Paper 410, p. 223-245.

Anderson, B.S., Schwartz, J.J., Johnson, K., Wooden, J.L., and Mueller, P.A., 2011, U-Pb geochronology and Hf isotope geochemistry of the Mountain Home metamorphic complex, Blue Mountains Province, northeastern Oregon: Geological Society of America Abstracts with Programs, v. 43, no. 4, p. 76.

Avé Lallemant, H.G., 1995, Pre-Cretaceous tectonic evolution of the Blue Mountains Province, northeastern Oregon, in Vallier, T.L., and Brooks, H.C., eds., Geology of the Blue Mountains Region of Oregon, Idaho, and Washington: Petrology and Tectonic Evolution of Pre-Tertiary Rocks of the Blue Mountains Region: U.S. Geological Survey Professional Paper 1438, p. $271-304$.

Barnes, C.G., Petersen, S.W., Kistler, R.W., Prestvik, T., and Sundvoll, B., 1992, Tectonic implications of isotopic variation among Jurassic and Early Cretaceous plutons, Klamath Mountains: Geological Society of America Bulletin, v. 104, p. 117-126, doi:10.1130 /0016-7606(1992)104<0117:TIOIVA>2.3.CO;2.

Bateman, P.C., 1983, A summary of critical relations in the central part of the Sierra Nevada Batholith, California, U.S.A., in Roddick, J.A., ed., Circum-Pacific Plutonic Terranes: Geological Society of America Memoir 159, p. 241-254.

Bateman, P.C., 1992, Plutonism in the Central Part of the Sierra Nevada Batholith, California: U.S. Geological Survey Professional Paper 1483, 186 p.

Batt, G.E., Harper, G.D., Heizler, M., and Roden-Tice, M., 2010a, Cretaceous sedimentary blanketing and tectonic rejuvenation in the Western Klamath Mountains: Insights from thermochronology: Central European Journal of Geosciences, v. 2, p. 138-151, doi:10.2478 /v10085-009-0041-4.

Batt, G.E., Cashman, S.M., Garver, J.I., and Bigelow, J.J., 2010b, Thermotectonic evidence for two-stage extension on the Trinity detachment surface, Eastern Klamath Mountains, California: American Journal of Science, v. 310, p. 261-281, doi:10.2475/04.2010.02.

Boehlke, J.K., and Kistler, R.W., 1986, Rb-Sr, K-Ar, and stable isotope evidence for the ages and sources of fluid components of gold-bearing quartz veins in the northern Sierra Nevada Foothills metamorphic belt, California: Economic Geology and the Bulletin of the Society of Economic Geologists, v. 81, p. 296-322, doi:10.2113/gsecongeo.81.2.296

Burchfiel, B.C., and Davis, G.A., 1972, Structural framework and evolution of the southern part of the Cordilleran orogen, western United States: American Journal of Science, v. 272, p. 97-118, doi:10.2475/ajs.272.2.97.
Burchfiel, B.C., Cowan, D.S., and Davis, G.A., 1992, Tectonic overview of the Cordilleran orogen in the western United States, in Burchfiel, B.C., Lipman, P.W., and Zoback, M.L., eds., The Cordilleran Orogen: Boulder, Colorado, Geological Society of America, The Geology of North America, v. G-3, p. 407-479.

Bywater, S.V., and Elliott, W.S., Jr., 2007, Petrographic analysis of sandstone concretions in the Upper Cretaceous Hornbrook Formation, Siskiyou County, California: Geological Society of America Abstracts with Programs, v. 39, no. 6, p. 628.

Cecil, M.R., Gehrels, G.E., Ducea, M.N., and Patchett, J., 2011, U-Pb-Hf characterization of the central Coast Mountains Batholith; implications for petrogenesis and crustal architecture: Lithosphere, v. 3, p. 247-260, doi:10.1130/L134.1.

Chen, J.H., and Moore, J.G., 1982, Uranium-lead isotopic ages from the Sierra Nevada Batholith, California: Journal of Geophysical Research, v. 87, p. 4761-4784, doi:10.1029/JB087iB06p04761.

Constenius, K.N., Johnson, R.A., Dickinson, W.R., and Williams, T.A., 2000, Tectonic evolution of the Jurassic-Cretaceous Great Valley forearc, California; implications for the Franciscan thrust-wedge hypothesis: Geological Society of America Bulletin, v. 112, p. 1703-1723, doi:10.1130/0016-7606(2000)112<1703: TEOTJC $>2.0 . \mathrm{CO} ; 2$.

Cowan, D.S., and Bruhn, R.L., 1992, Late Jurassic to early Late Cretaceous geology of the U.S. Cordillera, in Burchfiel, B.C., Lipman, P.W., and Zoback, M.L., eds. The Cordilleran Orogen: Boulder, Colorado, Geological Society of America, The Geology of North America, v. G-3, p. 169-189.

Cowan, D.S., Brandon, M.T., and Garver, J.I., 1997, Geologic tests of hypotheses for large coastwise displacements-A critique illustrated by the Baja British Columbia controversy: American Journal of Science, v. 297, p. 117-173, doi:10.2475/ajs.297.2.117.

Critelli, S., Le Pera, E., and Ingersoll, R.V., 1997, The effects of source lithology, transport, deposition and sampling scale on the composition of Southern California sand: Sedimentology, v. 44, p. 653-671, doi: 10.1046/j.1365-3091.1997.d01-42.x.

Cumming, G.L., and Richards, J.R., 1975, Ore lead isotope ratios in a continuously changing Earth: Earth and Planetary Science Letters, v. 28, p. 155-171, doi:10.1016/0012-821X(75)90223-X.

Darby, B.J., Wyld, S.J., and Gehrels, G.E., 2000, Provenance and paleogeography of the Black Rock terrane, north western Nevada: Implications of U-Pb detrital zircon geochronology, in Soreghan, M.J., and Gehrels, G.E. eds., Paleozoic and Triassic Paleogeography and Tectonics of Western Nevada and Northern California: Geological Society of America Special Paper 347, p. 77-88.

Davis, G.A., Monger, J.W.H., and Burchfiel, B.C., 1978 Mesozoic construction of the Cordilleran "collage" central British Columbia to central California, in Howell, D.G., and McDougall, K.A., eds., Mesozoic Paleogeography of the Western United States: Los Angeles, California, Pacific Section, Society of Economic Paleontologists and Mineralogists, Pacific Coast Paleogeography Symposium 2, p. 1-32.

DeGraaff-Surpless, K., Graham, S.A., Wooden, J.L. McWilliams, M.O., 2002, Detrital zircon provenance analysis of the Great Valley Group, California: Evolution of an arc-forearc system: Geological Society of America Bulletin, v. 114, p. 1564-1580.

DeGraaff-Surpless, K., Mahoney, J.B., Wooden, J.L., and McWilliams, M.O., 2003, Lithofacies control in detrital zircon provenance studies: Insights from the Cretaceous Methow Basin: Geological Society of America Bulletin, v. 115, no. 8, p. 899-915.

DePaolo, D.J., 1981, A neodymium and strontium isotopic study of the Mesozoic calc-alkaline granitic batholiths of the Sierra Nevada and Peninsular Ranges, California: Journal of Geophysical Research, v. 86, p. 10,470 10,488, doi:10.1029/JB086iB11p10470.

DePaolo, D.J., and Wasserburg, G.J., 1976, Nd isotopic variations and petrogenetic models: Geophysical Research Letters, v. 3, p. 249-252, doi:10.1029 /GL003i005p00249. 
Dickinson, W.R., 2004, Evolution of the North American Cordillera: Annual Review of Earth and Planetary Sciences, v. 32, p. 13-45, doi:10.1146/annurev .earth.32.101802.120257.

Dickinson, W.R., 2008a, Impact of differential zircon fertility of granitoid basement rocks in North America on age populations of detrital zircons and implications for granite petrogenesis: Earth and Planetary Science Letters, v. 275, p. 80-92, doi:10.1016/j.epsl.2008.08.003.

Dickinson, W.R., 2008b, Accretionary Mesozoic-Cenozoic expansion of the Cordilleran continental margin in California and adjacent Oregon: Geosphere, v. 4, p. 329353, doi:10.1130/GES00105.1.

Dickinson, W.R., and Gehrels, G.E., 2009a, Use of U-Pb ages of detrital zircons to infer maximum depositional ages of strata: A test against a Colorado Plateau Mesozoic database: Earth and Planetary Science Letters, v. 288 p. 115-125, doi:10.1016/j.epsl.2009.09.013.

Dickinson, W.R., and Gehrels, G.E., 2009b, U-Pb ages of detrital zircons in Jurassic eolian and associated sandstones of the Colorado Plateau: Evidence for transcontinental dispersal and intraregional recycling of sediment: Geological Society of America Bulletin, v. 121, p. 408-433, doi:10.1130/B26406.1.

Dickinson, W.R., and Thayer, T.P., 1978, Paleogeographic and paleotectonic implications of Mesozoic stratig raphy and structure in the John Day inlier of centra Oregon, in Howell, D.G., and McDougall, K.A., eds., Mesozoic Paleogeography of the Western United States: Los Angeles, California, Pacific Section, Society of Economic Paleontologists and Mineralogists, Pacific Coast Paleogeography Symposium 2, p. 147-161.

Dickinson, W.R., Beard, S.L., Brakenridge, G.R., Erjavec, J.L., Ferguson, R.C., Inman, K.F., Knepp, R.A., Lindberg, F.A., and Ryberg, P.T., 1983, Provenance of North American Phanerozoic sandstones in relation to tectonic setting: Geological Society of America Bulletin, v. 94, p. $222-235$, doi:10.1130/0016-7606(1983)94<222 PONAPS $>2.0 . \mathrm{CO} ; 2$.

Dorsey, R.J., and LaMaskin, T.A., 2007, Stratigraphic record of Triassic-Jurassic collisional tectonics in the Blue Mountains Province, northeastern Oregon: American Journal of Science, v. 307, p. 1167-1193, doi:10.2475 $/ 10.2007 .03$

Ducea, M., 2001, The California Arc: Thick granitic batholiths, eclogitic residues, lithospheric-scale thrusting, and magmatic flare-ups: GSA Today, v. 11, no. 11, p. 4-10.

Elliott, M.A., 1971, Stratigraphy and Petrology of the Late Cretaceous Rocks near Hilt and Hornbrook, Siskiyou County, California and Jackson County, Oregon [Ph.D. dissertation]: Corvallis, Oregon, Oregon State University, $171 \mathrm{p}$.

Engebretson, D.C., Cox, A., and Gordon, R.G., 1985, Relative Motions between Oceanic and Continental Plates in the Pacific Basin: Geological Society of America Special Paper 206, 59 p

Ernst, W.G., Snow, C.A., and Scherer, H.H., 2008, Contrasting early and late Mesozoic petrotectonic evolution of northern California: Geologic Society of America Bulletin, v. 120, p. 179-194.

Evernden, J.F., and Kistler, R.W., 1970, Chronology of Emplacement of Mesozoic Batholithic Complexes in California and Western Nevada: U.S. Geological Survey Professional Paper 0623, 42 p.

Gabrielse, H., 1985, Major dextral transcurrent displacements along the northern Rocky Mountain Trench and related lineaments in north-central British Columbia: Geological Society of America Bulletin, v. 96, p. 1-14 doi:10.1130/0016-7606(1985)96<1:MDTDAT>2.0.CO;2.

Gaschnig, R.M., Vervoort, J.D., Lewis, R.S., and McClelland, W.C., 2010, Migrating magmatism in the northern US Cordillera: In situ U-Pb geochronology of the Idaho Batholith: Contributions to Mineralogy and Petrology, v. 159, p. 863-883, doi:10.1007/s00410 -009-0459-5.

Gaschnig, R.M., Vervoort, J., Lewis, R.S., and Tikoff, B., 2011, Isotopic evolution of the Idaho Batholith and Challis intrusive province, northern US Cordillera: Journal of Petrology, v. 52, p. 2397-2429, doi:10.1093 /petrology/egr050.
Gehrels, G.E., 2000, Introduction to detrital zircon studies of Paleozoic and Triassic strata in western Nevada and northern California, in Soreghan, M.J., and Gehrels, G.E., eds., Paleozoic and Triassic Paleogeography and Tectonics of Western Nevada and Northern California: Geological Society of America Special Paper 347, p. 1-17

Gehrels, G.E., and Dickinson, W.R., 1995, Detrital zircon provenance of Cambrian to Triassic miogeoclinal and eugeoclinal strata in Nevada: American Journal of Science, v. 295, p. 18-48, doi:10.2475/ajs.295.1.18.

Gehrels, G.E., Valencia, V., and Pullen, A., 2006, Detrital zircon geochronology by laser-ablation multicollector ICPMS at the Arizona LaserChron Center, in Olszewski, T., ed., Geochronology: Emerging Opportunities: The Paleontological Society Papers, v. 12, p. 67-76.

Goldstein, S.L., O'Nions, R.K., and Hamilton, P.J., 1984, A Sm-Nd isotopic study of atmospheric dusts and particulates from major river systems: Earth and Planetary Science Letters, v. 70, p. 221-236, doi:10.1016 /0012-821X(84)90007-4

Golia, R.T., and Nilsen, T.H., 1984, Sandstone petrography of the Upper Cretaceous Hornbrook Formation, Oregon and California, in Nilsen, T.H., ed., Geology of the Upper Cretaceous Hornbrook Formation, Oregon and California: Los Angeles, California, Pacific Section, Society of Economic Paleontologists and Mineralogists, v. 42, p. 99-109.

Grasse, S.W., Gehrels, G.E., Lahren, M.M., Schweickert, R.A., and Barth, A.P., 2001, U-Pb geochronology of detrital zircons from the Snow Lake Pendant, central Sierra Nevada; implications for Late Jurassic-Early Cretaceous dextral strike-slip faulting: Geology, v. 29, p. 307-310, doi:10.1130/0091-7613(2001)029<0307: UPGODZ>2.0. CO 2

Grove, M., Gehrels, G.E., Cotkin, S.J., Wright, J.E., and Zou, H., 2008, Non-Laurentian cratonal provenance of Late Ordovician eastern Klamath blueschists and a link to the Alexander terrane, in Wright, J.E., and Shervais, J.W., eds., Ophiolites, Arcs, and Batholiths: A Tribute to Cliff Hopson: Geological Society of America Special Paper 438, p. 223-250.

Hacker, B.R., Donato, M.M., Barnes, C.G., McWilliams, M.O., and Ernst, W.G., 1995, Timescales of orogeny; Jurassic construction of the Klamath Mountains: Tectonics, v. 14, p. 677-703.

Haggart, J.W., Enkin, R.J., and Monger, J.W.H., 2006 , Strengths and limitations of paleogeographic methods in assessing large-scale displacements within the North American Cordillera, in Haggart, J.W., Enkin, R.J., and Monger, J.W.H., eds., Paleogeography of the North American Cordillera: Evidence For and Against Large-Scale Displacements: Geological Association of Canada Special Paper 46, p. 1-11.

Hanchar, J.M., and Miller, C.F., 1993, Zircon zonation patterns as revealed by cathodoluminescence and backscattered electron images; implications for interpretation of complex crustal histories, in Watson, E.B., Harrison, T.M., Miller, C.F., and Ryerson, F.J., eds., Geochemistry of Accessory Minerals; Papers Presented at the Third V.M. Goldschmidt Conference: Amsterdam, Netherlands: Chemical Geology, v. 110, p. 1-13.

Harding, J.P., Gehrels, G.E., Harwood, D.S., and Girty, G.H., 2000, Detrital zircon geochronology of the Shoo Fly complex, northern Sierran terrane, northeastern California, in Soreghan, M.J., and Gehrels, G.E., eds., Paleozoic and Triassic Paleogeography and Tectonics of Western Nevada and Northern California: Geological Society of America Special Paper 347, p. 43-56.

Housen, B.A., and Dorsey, R.J., 2002, Tectonic significance of paleomagnetic results from the Ochoco and Hornbrook basins, Oregon: Geological Society of America Abstracts with Programs, v. 34, no. 5, p. 103.

Ingersoll, R.V., 1979, Evolution of the Late Cretaceous forearc basin, northern and central California: Geological Society of America Bulletin, v. 90, p. 813-826, doi: 10.1130/0016-7606(1979)90<813:EOTLCF>2.0.CO;2.

Ingersoll, R.V., 1983, Petrofacies and provenance of late Mesozoic forearc basin: Northern and Central California: American Association of Petroleum Geologists Bulletin, v. 67, p. 1125-1142.
Ingersoll, R.V., Kretchmer, A.G., and Valles, P.K., 1993 The effect of sampling scale on actualistic sandstone petrofacies: Sedimentology, v. 40, p. 937-953, doi: 10.1111/j.1365-3091.1993.tb01370.x

Irving, E., Wynne, P.J., Throkelson, D.J., and Schiarizza, P., 1996, Large (1000 to $4000 \mathrm{~km}$ ) northward movements of tectonic domains in the northern Cordillera, 83-45 Ma: Journal of Geophysical Research, v. 101, p. 17,901-17,916, doi:10.1029/96JB01181.

Irwin, W.P., 1960, Geologic Reconnaissance of the Northern Coast Ranges and Klamath Mountains, California, with a Summary of the Mineral Resources: California Division of Mines Bulletin 179, $80 \mathrm{p}$.

Irwin, W.P., 1981, Tectonic accretion of the Klamath Mountains, in Ernst, W.G., ed., The Geotectonic Development of California (Rubey Volume I): Englewood Cliffs, New Jersey, Prentice Hall, p. 30-49.

Irwin, W.P., 2003, Correlation of the Klamath Mountains and Sierra Nevada: U.S. Geological Survey Open-File Report 02-490.

Irwin, W.P., and Wooden, J.L., 1999, Plutons and Accretionary Episodes of the Klamath Mountains, California: U.S. Geological Survey Open-File Report 99-374.

Jameossanaie, A., and Lindsley-Griffin, N., 1993, Palynology and plate tectonics: A case study on Cretaceous terrestrial sediments in the eastern Klamath Mountains of Northern California, USA: Palynology, v. 17, p. 1145, doi:10.1080/01916122.1993.9989417.

Jones, A.E., 1990, Geology and tectonic significance of terranes near Quinn River Crossing, Nevada, in Harwood, D.S., and Miller, M.M., eds., Late Paleozoic and Early Mesozoic Paleogeographic Relations: Klamath Mountains, Sierra Nevada, and Related Terranes: Geologica Society of America Special Paper 255, p. 239-254.

Jones, D.L., 1959, Stratigraphy of Upper Cretaceous rocks in the Yreka-Hornbrook area, northern California: Geological Society of America Bulletin, v. 70, p. 1726-1727.

Jones, D.L., and Irwin, W.P., 1971, Structural implications of an offset Early Cretaceous shoreline in northern Cali fornia: Geological Society of America Bulletin, v. 82, p. 815-822, doi:10.1130/0016-7606(1971)82[815. SIOAOE]2.0.CO;2

Lackey, J.S., Cecil, M.R., Windham, C.J., Frazer, R.E., Bindeman, I.N., and Gehrels, G.E., 2010, Igniting the Sierran arc: Evolving oxygen and hafnium isotope ratios in the Bass Lake tonalite: Geological Society of America Abstracts with Programs, v. 42, no. 4, p. 110.

Lahren, M.M., and Schweickert, R.A., 1994, Sachse Monument pendant, central Sierra Nevada, California; eugeoclinal metasedimentary rocks near the axis of the Sierra Nevada Batholith: Geological Society of America Bulletin, v. 106, p. 186-194, doi:10.1130/0016 -7606(1994)106<0186:SMPCSN>2.3.CO 2.

LaMaskin, T.A., 2012, Detrital zircon facies of Cordilleran terranes in western North America: GSA Today, v. 22, no. 3 , p. $4-11$

LaMaskin, T.A., Dorsey, R.J., and Vervoort, J.D., 2008 , Tectonic controls on mudrock geochemistry, Mesozoic rocks of eastern Oregon and western Idaho, U.S.A. Implications for Cordilleran tectonics: Journal of Sedimentary Research, v. 78, p. 765-783, doi:10.2110 /jsr.2008.087.

LaMaskin, T.A., Vervoort, J.D., Dorsey, R.J., and Wright, J.E., 2011, Early Mesozoic paleogeography and tectonic evolution of the western United States; insight from detrital zircon U-Pb geochronology, Blue Mountains Province, northeastern Oregon: Geological Society of America Bulletin, v. 123, p. 1939-1965, doi: 10.1130/B30260.1

Lanphere, M.A., and Jones, D.L., 1978, Cretaceous time scale from North America, in Cohee, G.V., Glaessner, M.F., and Hedberg, H.D., eds., Contributions to the Geologic Time Scale: Tulsa, Oklahoma, Studies in Geology, v. 6, p. 259-268

Lerch, D.W., Klemperer, S.L., Glen, J.M.G., Ponce, D.A., and Miller, E.L., 2007, Crustal structure of the northwestern Basin and Range Province and its transition to unextended volcanic plateaus: Geochemistry, Geophysics, Geosystems, v. 8, 21 p., doi:10.1029/2006GC001429.

Lewis, R.S., Kiilsgaard, T.H., Bennett, E.H., and Hall, W.E., 1987, Lithologic and chemical characteristics of the 
central and southeastern part of the southern lobe of the Idaho Batholith, in Valllier, T.L., and Brooks, H.C., eds., Geology of the Blue Mountains Region of Oregon, Idaho, and Washington; the Idaho Batholith and its Border Zone: U.S. Geological Survey Professional Paper 1436, p. 171-196.

Linn, A.M., DePaolo, D.J., and Ingersoll, R.V., 1991, Nd$\mathrm{Sr}$ isotopic provenance analysis of Upper Cretaceous Great Valley fore-arc sandstones: Geology, v. 19, p. 803-806, doi:10.1130/0091-7613(1991)019<0803: NSIPAO $>2.3 . \mathrm{CO} ; 2$.

Linn, A.M., DePaolo, D.J., and Ingersoll, R.V., 1992, Nd-Sr isotopic, geochemical, and petrographic stratigraphy and paleotectonic analysis; Mesozoic Great Valley forearc sedimentary rocks of California: Geological Society of America Bulletin, v. 104, p. 1264-1279, doi:10.1130 /0016-7606(1992)104<1264:NSIGAP>2.3.CO;2.

Liu, L., Spasojevic, S., and Gurnis, M., 2008, Reconstructing Farallon plate subduction beneath North America back to the Late Cretaceous: Science, v. 322, p. 934 938, doi:10.1126/science.1162921.

Manduca, C.A., Kuntz, M.A., and Silver, L.T., 1993, Emplacement and deformation history of the western margin of the Idaho Batholith near McCall, Idaho; influence of a major terrane boundary: Geological Society of America Bulletin, v. 105, p. 749-765, doi:10.1130 /0016-7606(1993)105<0749:EADHOT>2.3.CO;2.

Mankinen, E.A., 1984, Implications of paleomagnetism for the tectonic history of the Eastern Klamath and related terranes in California and Oregon, in Nilsen, T.H., ed., Geology of the Upper Cretaceous and Hornbrook Formation, Oregon and California: Pacific Section, Society of Economic Paleontologists and Mineralogists, Book 42, p. 221-229.

Mankinen, E.A., and Irwin, W.P., 1990, Review of paleomagnetic data from the Klamath Mountains Blue Mountains, and Sierra Nevada: Implications for paleogeographic reconstructions, in Harwood, D.S., and Miller, M.M., eds., Paleozoic and Early Mesozoic Paleogeographic Relations; Sierra Nevada, Klamath Mountains, and Related Terranes: Geological Society of America Special Paper 255, p. 397-407.

Martin, A.J., Wyld, S.J., Wright, J.E., and Bradford, J.H., 2010, The Lower Cretaceous King Lear Formation, northwest Nevada: Implications for Mesozoic orogenesis in the western U.S. Cordillera: Geological Society of America Bulletin, v. 122, p. 537-562, doi:10.1130 /B26555.1.

McKnight, B.K., 1971, Petrology and Sedimentation of Cretaceous and Eocene Rocks in the Medford-Ashland Region, Southwestern Oregon [Ph.D. dissertation]: Corvallis, Oregon, Oregon State University, 177 p.

Miller, D.M., Nilsen, T.H., and Bilodeau, W.L., 1992, Late Cretaceous to early Eocene geologic evolution of the U.S. Cordillera, in Burchfiel, B.C., Lipman, P.W., and Zoback, M.L., eds., The Cordilleran Orogen: Boulder, Colorado, Geological Society of America, The Geology of North America, v. G-3, p. 205-260.

Moecher, D.P., and Samson, S.D., 2006, Differential zircon fertility of source terranes and natural bias in the detrital zircon record: Implications for sedimentary provenance analysis: Earth and Planetary Science Letters, v. 247 , p. 252-266, doi:10.1016/j.epsl.2006.04.035.

Monger, J.W.H., 1991, Structural evolution of the southwestern Intermontane Belt, Ashcroft and Hope map areas, British Columbia: Geological Survey of Canada Current Research, Part A, v. 85-1A, p. 349-358.

Moxon, I.W., 1990, Stratigraphic and Structural Architecture of the San Joaquin-Sacramento Basin [Ph.D. thesis]: Stanford University, $371 \mathrm{p}$.

Nilsen, T.H., 1984, Stratigraphy, sedimentology, and tectonic framework of the Upper Cretaceous Hornbrook Formation, Oregon and California, in Nilsen, T.H., ed., Geology of the Upper Cretaceous Hornbrook Formation, Oregon and California: Los Angeles, California, Pacific Section, Society of Economic Paleontologists and Mineralogists, v. 42 , p. $51-88$.

Nilsen, T.H., 1993, Stratigraphy of the Cretaceous Hornbrook Formation, Southern Oregon and Northern California: U.S. Geological Survey Professional Paper 1521, 89 p.

Northrup, C.J., Schmitz, M., Kurz, G., and Tumpane, K., 2011, Tectonomagmatic evolution of distinct arc ter- ranes in the Blue Mountains Province, Oregon and Idaho, in Lee, J., and Evans, J.P., eds., Geologic Field Trips to the Basin and Range, Rocky Mountains, Snake River Plain, and Terranes of the U.S. Cordillera: Geological Society of America Field Guide 21, p. 67-88.

Peck, D.L., Imlay, R.W., and Popenoe, W.P., 1956, Upper Cretaceous rocks of parts of southwestern Oregon and northern California: American Association of Petroleum Geologists Bulletin, v. 40, p. 1968-1984.

Poldervaart, A., 1956, Zircon in rocks: 2. Igneous rocks: American Journal of Science, v. 254, p. 521-554, doi: 10.2475/ajs.254.9.521.

Quinn, M.J., Wright, J.E., and Wyld, S.J., 1997, Happy Creek igneous complex and tectonic evolution of the early Mesozoic arc in the Jackson Mountains, northwest Nevada: Geological Society of America Bulletin, v. 109, p. 461-482, doi:10.1130/0016-7606(1997)109<0461: HCICAT>2.3.CO;2.

Renne, P.R., Tobisch, O.T., and Saleeby, J.B., 1993, Thermochronologic record of pluton emplacement, deformation, and exhumation at Courtright shear zone, centra Sierra Nevada, California: Geology, v. 21, p. 331-334, doi:10.1130/0091-7613(1993)021<0331:TROPED $>2.3 . \mathrm{CO} ; 2$.

Saleeby, J.B., 2003, Segmentation of the Laramide slab; evidence from the southern Sierra Nevada region: Geological Society of America Bulletin, v. 115, p. $655-668$, doi:10.1130/0016-7606(2003)115<0655: SOTLSF $>2.0 . \mathrm{CO} ; 2$

Saleeby, J.B., Geary, E.E., Paterson, S.R., and Tobisch, O.T., 1989, Isotopic systematics of $\mathrm{Pb} / \mathrm{U}$ (zircon) and ${ }^{40} \mathrm{Ar} /{ }^{39} \mathrm{Ar}$ (biotite-hornblende) from rocks of the central Foothills terrane, Sierra Nevada, California: Geological Society of America Bulletin, v. 101, p. 1481-1492, doi:10.1130 /0016-7606(1989)101<1481:ISOPUZ>2.3.CO;2.

Saleeby, J.B., Busby-Spera, C., Oldow, J.S., Dunne, G.C., Wright, J.E., Cowan, D.S., Walker, N.W., and Allmendinger, R.W., 1992, Early Mesozoic tectonic evolution of the Western U.S. Cordillera, in Burchfiel, B.C., Lipman, P.W., and Zoback, M.L., eds., The Cordilleran Orogen: Boulder, Colorado, Geological Society of America, The Geology of North America, v. G-3, p. 107-168.

Saleeby, J.B., Saleeby, Z., Liu, L., and Maheo, G., 2010 Mid-Cretaceous regional exhumation of the Sierra Nevada-Great Valley Batholith and a possible tectonic driving mechanism: Abstracts with Programs Geological Society of America, v. 42, no. 4, p. 67

Scherer, H.H., Ernst, W.G., and Wooden, J.L., 2010, Regional detrital zircon provenance of exotic metasandstone blocks, Eastern Hayfork terrane, western Paleozoic and Triassic belt, Klamath Mountains, California: The Journal of Geology, v. 118, p. 641-653, doi:10.1086 1656352.

Schwartz, J.J., Snoke, A.W., Cordrey, F., Johnson, K., Frost, C.D., Barnes, C.G., LaMaskin, T.A., and Wooden, J.L., 2011, Late Jurassic magmatism, metamorphism, and deformation in the Blue Mountains Province, northeast Oregon: Geological Society of America Bulletin, v. 123, p. 2083-2111, doi:10.1130/B30327.1.

Snee, L.W., Lund, K., Sutter, J.F., Balcer, D.E., and Evans, K.V., 1995, An ${ }^{40} \mathrm{Ar} /{ }^{39} \mathrm{Ar}$ chronicle of the tectonic development of the Salmon River suture zone, western Idaho, in Vallier, T.L., and Brooks, H.C., eds., Geology of the Blue Mountains Region of Oregon, Idaho, and Washington; Petrology and Tectonic Evolution of Pre-Tertiary Rocks of the Blue Mountains region: U.S. Geological Survey Professional Paper 1438, p. $359-414$

Snoke, A.W., and Barnes, C.G., eds., 2006, Geological Studies in the Klamath Mountains Province, California and Oregon; A Volume in Honor of William P. Irwin: Geological Society of America Special Paper 410, 505 p.

Snow, C.A., and Scherer, H., 2006, Terranes of the western Sierra Nevada foothills metamorphic belt, California; a critical review: International Geology Review, v. 48, p. 46-62, doi:10.2747/0020-6814.48.1.46.

Spurlin, M.S., Gehrels, G.E., and Harwood, D.S., 2000, Detrital zircon geochronology of Upper Paleozoic and Lower Mesozoic strata of the northern Sierran terrane, northeastern California, in Soreghan, M.J., and Gehrels, G.E., eds., Paleozoic and Triassic Paleogeography and
Tectonics of Western Nevada and Northern California: Geological Society of America Special Paper 347, p. 89-98.

Stern, T.W., Bateman, P.C., Morgan, B.A., Newell, M.F., and Peck, D.L., 1981, Isotopic U-Pb ages of zircon from the granitoids of the central Sierra Nevada, California: U.S. Geological Survey Professional Paper $1185,17 \mathrm{p}$.

Tobisch, O.T., Saleeby, J.B., Renne, P.R., McNulty, B.A. and Tong, W., 1995, Variations in deformation fields during development of a large-volume magmatic arc central Sierra Nevada, California: Geological Society of America Bulletin, v. 107, p. 148-166, doi:10.1130 /0016-7606(1995)107<0148:VIDFDD>2.3.CO;2.

Todt, M.K., Surpless, K.D., and Shaw, B.R.G., 2011, Testing the utility of detrital zircon hafnium signatures for sedimentary provenance in the northern Great Valley Group, California: Geological Society of America Abstracts with Programs, v. 43, no. 4, p. 68.

Umhoefer, P.J., and Schiarizza, P., 1996, Latest Cretaceous to early Tertiary dextral strike-slip faulting on the southeastern Yalakom fault system, southeastern Coast Belt, British Columbia: Geological Society of America Bulletin, v. 108, p. 768-785, doi:10.1130 /0016-7606(1996)108<0768:LCTETD>2.3.CO;2.

Van Buer, N.J., Miller, E.L., and Dumitru, T.A., 2009, Early Tertiary paleogeologic map of the northern Sierra Nevada Batholith and the northwestern Basin and Range: Geology, v. 37, p. 371-374.

Vermeesch, P., 2004, How many grains are needed for a provenance study?: Earth and Planetary Science Letters, v. 224, p. 441-451, doi:10.1016/j.epsl.2004 .05 .037 .

Walker, J.D., and Geissman, J.W., 2009, 2009 GSA geologic time scale: GSA Today, v. 19, no. 4, p. 60-61, doi:10.1130/1052-5173-19.4-5.60.

Walker, N.W., 1995, Tectonic implications of U-Pb zircon ages of the Canyon Mountain complex, Sparta complex, and related metaplutonic rocks of the Baker terrane, northeastern Oregon in Vallier, T.L., and Brooks, H.C., eds., Geology of the Blue Mountains region of Oregon, Idaho, and Washington: Petrology and tectonic evolution of pre-Tertiary rocks of the Blue Mountains region: U.S. Geological Survey Professional Paper 1438, p. 247-269.

Wallin, E.T., Noto, R.C., and Gehrels, G.E., 2000, Provenance of the Antelope Mountain Quartzite, Yreka terrane, California: Evidence for large-scale sinistral displacement along the North American Cordilleran margin and implications for the mid-Paleozoic fringing-arc model, in Soreghan, M.J., and Gehrels, G.E., eds., Paleozoic and Triassic Paleogeography and Tectonics of Western Nevada and Northern California: Geological Society of America Special Paper 347, p. 119-131.

Watson, B.E., and Harrison, T.M., 1983, Zircon saturation revisited; temperature and composition effects in a variety of crustal magma types: Earth and Planetary Science Letters, v. 64, p. 295-304, doi:10.1016/0012 $-821 X(83) 90211-X$

Wilson, D., and Cox, A., 1980, Paleomagnetic evidence for the tectonic rotation of Jurassic plutons in the Blue Mountains, eastern Oregon: Journal of Geophysical Research, v. 85 , p. 3681-3689, doi:10.1029 /JB085iB07p03681.

Woods, M.T., and Davies, G.F., 1982, Late Cretaceous genesis of the Kula plate: Earth and Planetary Science Letters, v. 58, p. 161-166, doi:10.1016/0012-821X(82)90191-1.

Wright, J.E., and Wyld, S.J., 2007, Alternative tectonic model for Late Jurassic through Early Cretaceous evolution of the Great Valley Group, California, in Cloos, M., Carlson, W.D., Gilbert, M.C., Liou, J.G., and Sorenson, S.S., eds., Convergent Margin Terranes and Associated Regions: A Tribute to W.G. Ernst: Geological Society of America Special Paper 419, p. 1-15.

Wyld, S.J., 1990, Paleozoic and Mesozoic rocks of the Pine Forest Range, northwest Nevada, and their relation to volcanic arc assemblages of the western U.S. Cordillera, in Harwood, D.S., and Miller, M.M., eds., Paleozoic and Early Mesozoic Paleogeographic Relations; Sierra Nevada, Klamath Mountains, and Related Terranes: Geological Society of America Special Paper 255, p. 219-237. 
Wyld, S.J., 1996, Early Jurassic deformation in the Pine Forest Range, northwest Nevada, and implications for Cordilleran tectonics: Tectonics, v. 15 , p. 566-583, doi:10.1029/95TC03693.

Wyld, S.J., Umhoefer, P.J., and Wright, J.E., 2006, Reconstructing northern Cordilleran terranes along known Cretaceous and Cenozoic strike-slip faults: Implications for the Baja British Columbia hypothesis and other models, in Haggart, J.W., Enkin, R.J., and Monger, J.W.H., eds., Paleo- geography of the North American Cordillera: Evidence For and Against Large-Scale Displacements: Geological Association of Canada Special Paper 46, p. 277-298.

Wynne, P.J., Irving, E., Maxson, J.A., and Kleinspehn, K.L., 1995, Paleomagnetism of the Upper Cretaceous strata of Mount Tatlow; evidence for $3000 \mathrm{~km}$ of northward displacement of the eastern Coast Belt, British Columbia: Journal of Geophysical Research, v. 100, no. B4, p. 6073-6091.
SCIENCE Editor: NANCy Rigg Associate Editor: Rebecca Dorsey

MANusCRIPT Received 29 February 2012

Revised Manuscript Received 30 August 2012 MANUSCRIPT ACCEPTED 10 SePTEMber 2012

Printed in the USA 